Cebrián Fernández, R., Andreu Pintado, J., Romero Novella, L., Mateo Pérez, R.y Delage González, I. (2020): "Arquitectura pública de Santa Criz de Eslava (Navarra, conventus Caesaraugustanus) en época altoimperial: el criptopórtico del foro y su almacén anexo", Spal 29.1: 213-242. DOI: http://dx.doi.org/10.12795/spal.2020.i29.08

\title{
ARQUITECTURA PÚBLICA DE SANTA CRIZ DE ESLAVA (NAVARRA, CONVENTVS CAESARAVGVSTANVS) EN ÉPOCA ALTOIMPERIAL: EL CRIPTOPÓRTICO DEL FORO Y SU ALMACÉN ANEXO

\author{
PUBLIC ARCHITECTURE IN SANTA CRIZ DE ESLAVA (NAVARRA, CONVENTUS \\ CAESARAVGVSTANVS) IN EARLY IMPERIAL PERIOD: THE FORUM \\ CRYPTOPORTICUS AND THE STORE BUILDING
}

\author{
ROSARIO CEBRIÁN FERNÁNDEZ. \\ Dpto. de Prehistoria, Historia Antigua y Arqueología. Fac. de Geografía e Historia \\ Universidad Complutense de Madrid. C/ Profesor Aranguren, s/no, 28040 Madrid \\ Correo-e: marcebri@ucm.es. (D) http://orcid.org/0000-0002-5560-1191 \\ Researcher ID: <https://publons.com/researcher/AAG-9091-2019> \\ JAVIER ANDREU PINTADO \\ Responsable de la correspondencia \\ Dpto. de Historia, Historia de Arte y Geografía, Fac. de Filosofía y Letras \\ Universidad de Navarra. Crtra. Río Sadar s/n, 31900 Pamplona (Navarra) \\ Correo-e: jandreup@unav.es. D https://orcid.org/0000-0003-4662-548X \\ Researcher ID: <https://publons.com/researcher/AAG-8246-2019> \\ LUIS ROMERO NOVELLA \\ Dpto. de Historia, Historia de Arte y Geografía, Fac. de Filosofía y Letras \\ Universidad de Navarra. Crtra. Río Sadar s/n, 31900 Pamplona (Navarra) \\ Correo-e: Iromero@alumni.unav.es. (D) http://orcid.org/0000-0002-2184-2296 \\ Researcher ID: <https://publons.com/researcher/AAG-9507-2019> \\ ROSARIO MATEO PÉREZ \\ Olcairum Estudios Arqueológicos S. L. Bulevar Anelier, 18, 1응. 31014 Pamplona (Navarra) \\ Correo-e: olcairum@gmail.com. (D) https://orcid.org/0000-0001-6279-5628 \\ Researcher ID: <https://publons.com/researcher/AA-8913-2019> \\ INMACULADA DELAGE GONZÁLEZ \\ Dpto. de Historia, Historia de Arte y Geografía, Fac. de Filosofía y Letras \\ Universidad de Navarra. Crtra. Río Sadar s/n, 31900 Pamplona (Navarra) \\ Correo-e: idelage@alumni.unav.es. (D) http://orcid.org./0000-0002-2393-1495 \\ Researcher ID: <https://publons.com/researcher/AAG-9403-2019>
}

Resumen: A partir de un castrum de la Edad del Hierro surgió en Santa Criz de Eslava una civitas en territorio vascón, cuya base económica fue la agricultura. La ampliación de la muralla en época tardorrepublicana explica el papel territorial que alcanzó en el valle medio del Ebro y la buena situación respecto a la red de comunicaciones terrestres. Alcanzó 13 ha de extensión. Integrada en el conventus Caesaraugustanus, en época augustea inició importantes trabajos de urbanización a la manera romana con la construcción de un conjunto
Abstract: With origin as an Iron Age II settlement, Santa Criz de Eslava was a Roman civitas in the Vascones' territory with an economy based in agriculture. The ampliation of the city walls during the Late Republic shows the territorial importance that the city reached in the center of the Ebro Valley and its well-connected position concerning the roadsystem. During that Roman period the city covered 13 Has. Integrated in the conventus Caesaraugustanus, in the Augustan times the city began to undertake important public works 
público de carácter monumental. Las excavaciones recientes (2007-2016) han puesto al descubierto el criptopórtico, que sostenía el porticado sur de la plaza forense, y un almacén contiguo. El estudio completo de su estructura arquitectónica y decoración permite ahora el análisis de su interpretación funcional, el establecimiento de la fase constructiva inicial y reformas y una propuesta de restitución de su espacio público.

Palabras clave: Vascones, ciudades romanas, urbanismo hispanorromano, monumentalización urbana, arquitectura pública, foros romanos.

En septiembre de 1944, los arqueólogos B. Taracena y L. Vázquez de Parga llevaron a cabo la primera excavación en el cerro de Santa Criz de Eslava (Navarra), cuyo informe no fue publicado, pero una sucinta referencia a los hallazgos en uno de sus trabajos advertía de la riqueza arqueológica del subsuelo de este enclave, rodeado de cierta mitología en la arqueología de Navarra (Andreu et al. 2019b: 14-21). Del terreno asomaban dos capiteles toscanos, otro de orden corintio, un fragmento de fuste decorado con hojas imbricadas y varios fustes acanalados de los que ya había hablado, algo antes, el jesuita del castillo de Javier, F. Escalada (1943: 119). En las excavaciones practicadas se descubrieron, a poca profundidad, algunos lienzos murarios correspondientes a viviendas, una de las cuales presentaba un atrio con impluvium. Se localizó también un paramento de grandes sillares, que identificaron con la cimentación de un templo, y recogieron un gran número de fragmentos cerámicos de terra sigillata (Taracena y Vázquez de Parga 1946: 427).

En la década de los años 90 del siglo XX comenzó la investigación arqueológica reciente en el lugar -la única, hasta la fecha, continuada y sistemática- con la realización de varios sondeos en la muralla del castro de la Edad del Hierro, criptopórtico del foro y área cementerial de cronología altoimperial situada a los pies del cerro por su lado meridional (Arméndariz et al. 1996: 322-326). Durante el período 2007-2016 los esfuerzos se centraron en la exhumación del conjunto forense, que concluyeron con la puesta en valor del área excavada.

El resultado de estos trabajos se publicó en un artículo en el que se describían las estructuras excavadas y se establecía la secuencia evolutiva del conjunto a partir del análisis de las fábricas murarias y de los materiales cerámicos recuperados (Armendáriz et al. 2016). Una nueva lectura e interpretación de los datos leading to its urban development. Recent archaeological excavations (2007-2016) has discovered the cryptoporticus, which sustained the porticoes of the south side of the forum, and its adjacent depot. A complete study of the architectonic structure and its decoration allow us now to the whole analysis of both its function and its final aspect, the fixing of its early stage, its reforms and a proposal of reconstruction to the whole public area.

Keywords: Vascones, Roman cities, Hispanoroman urbanism, Public architecture, Roman forums.

arqueológicos, que aquí presentamos, permite abordar el estudio arquitectónico del conjunto, el establecimiento de la fase constructiva inicial y reformas, el análisis de los elementos decorativos y una propuesta de restitución del complejo monumental. Sin embargo, es necesario advertir que los trabajos arqueológicos no han concluido, por lo que nuestra aportación es necesariamente susceptible de ser modificada en el futuro a partir de los nuevos hallazgos que puedan sucederse.

\section{EL CONTEXTO TOPOGRÁFICO E HISTÓRICO}

El cerro de Santa Criz tiene planta trapezoidal y está constituido por dos cimas amesetadas de forma triangular, una en su extremo oeste elevada 545 m s.n.m. y otra al este de 542 m s.n.m, entre las que se sitúa una zona llana que discurre a la cota de $530 \mathrm{~m}$. Los flancos del cerro descienden pronunciadamente hasta alcanzar la cota de 515-510 m. Está situado a orillas del barranco de Pisaldea en el curso medio del Indusi, afluente del río Aragón, que discurre por su lado septentrional. Dos arroyos de este barranco recorren los costados del cerro, uno por el lado occidental de $1.400 \mathrm{~m}$ y otro por el oriental de $1.860 \mathrm{~m}$.

Los yacimientos agrarios de época romana en torno al fértil valle de la Val de Aibar son numerosos. De hecho, los trabajos de prospección arqueológica han documentado cerca de medio centenar en el posible territorio adscrito a la civitas ignota de Santa Criz (Armendáriz et al. 1997: 154). A partir del siglo I d.C. se instalarán, en torno a Santa Criz de Eslava, villae dedicadas a la explotación agrícola, entre las que se encuentra la villa de Valuriáin ocupando una pequeña elevación al noroeste de la civitas, que conserva restos de una prensa de viga y materiales cerámicos adscritos a época flavia. Algunos de esos enclaves alcanzaron 
notable protagonismo en la vertebración territorial sobreviviendo, incluso, a la propia ciudad romana, caso del ubicado en La Venta, entre el núcleo urbano actual de Eslava y Santa Criz, que aparece, incluso, citado en la documentación medieval y del que procede un representativo repertorio epigráfico (Andreu et al. 2019b: 54-55, además de Andreu et al. 2019a, para toda la cultura material de la civitas).

Pese a su aparente situación excéntrica, Santa Criz de Eslava ocupó un lugar importante y nada desdeñable, desde el punto de vista estratégico, en la red de comunicaciones que vertebró el norte del distrito jurídico de Caesar Augusta al que el enclave pertenecía, precisamente a partir de la fundación de la colonia por Augusto en el 15-14 a.C. (Beltrán Lloris 2017). Por un lado, a los pies del cerro, por el centro de la Val de Aibar, pasó la vía Iacca-Vareia que ha concentrado el catálogo de miliarios descubiertos en el territorio actualmente navarro y que desde el Pirineo central, tras pasar por el importante nudo viario de Campo Real/ Fillera se dirigía por Santa Criz, Andelo (Mendigorría, Navarra) y Curnonium (Los Arcos, Navarra) hacia $\mathrm{Va}$ reia (Varea, Logroño), último puerto navegable en la vía del Ebro (Andreu y Armendáriz 2018). A esa vía pertenecieron, de hecho, los dos miliarios que, publicado el primero en 1917 por J. Castrillo y el segundo poco después por F. Fita (CIL XVII-1, 188 y 189), darían a conocer Santa Criz de Eslava a la comunidad científica en las primeras décadas del siglo XX (Andreu et al. 2019b: 15-16). No lejos del enclave discurriría además la denominada "vía romana de las Cinco Villas", en realidad la Caesar Augusta-Beneharnum (Moreno 2008), con un ramal por Los Bañales de Uncastillo, Cabezo Ladrero de Sofuentes y Campo Real/ Fillera de Sos del Rey Católico, que alcanzaría la Jacetania atravesando la Canal de Berdún y, a partir de época de Tiberio, con otro por el valle del río Aragón que prestaría importancia a la ciudad de los Carenses (Santacara, Navarra) y que correspondería con la denominada "vía del Ravenate" (Castiella 2003: 71-73).

Con ese panorama en términos de conectividad, el territorio circundante a la ciudad romana de Santa Criz de Eslava exhibe uno de los más intensos grados de urbanización del área septentrional del citado conventus. Así, además de las civitates mencionadas -algunas de ellas reducidas, como se ha visto, a topónimos citados en los textos antiguos (Andreu 2006)-, las fuentes ubican a apenas 30 kilómetros de Santa Criz, hacia el norte y al otro lado de la Sierra de Izco, que cierra por el norte la Val de Aibar, la civitas de los Iluberitani. Citada por Plinio entre los oppida stipendiaria del distrito cesaraugustano (Plin. Nat. 3. 24), se identifica con la actual localidad navarra de Lumbier. Iluberis conoció también, en su posición en altura, un notable proceso de monumentalización con foro aterrazado sobre estructuras de opus caementicium prácticamente inédito hasta la fecha (Romero 2014: 207-209). Esa intensidad de la urbanización complica la adscripción del yacimiento que nos ocupa a alguna de las comunidades citadas bien en la lista de la Naturalis Historia de Plinio bien en la de las póleis de los Vascones ofrecida por Ptolomeo (Ptol. 2.6.67). Cierto éxito han tenido en la investigación las propuestas de R. Armendáriz, P. Sáez y R. Mateo, de identificar el lugar con la Nemanturissa de dichos listados o la que, argumentada por J. L. Ramírez Sádaba, ha buscado en Santa Criz la Bituris del propio Ptolomeo (Andreu et al. 2019b: 11, con toda la bibliografía). Sin embargo, ninguna de esas propuestas, a día de hoy y a falta de prueba epigráfica, puede confirmarse (fig. 1).

Sí es cierto que Santa Criz de Eslava - como demuestran las inscripciones de Lerga (IRMN 50) y de Ujué (IRMN 34)- se encuentra en una zona que el propio J. L. Ramírez Sádaba (2009) caracterizó como de predominio lingüístico vascónico en, al menos, la toponimia -aunque también en la onomástica y en la teonimia (Velaza 1995)- y que por tanto un nombre como Nemanturissa encajaría bien en dicho contexto vasconizado. Sin embargo, la ausencia de confirmación epigráfica y, especialmente, la mezcla cultural -con evidentes rasgos indoeuropeos- que puede inferirse de la onomástica atestiguada en sus inscripciones (Andreu 2018) deja el tema abierto todavía. Sí parece claro que, como se ha subrayado recientemente (Andreu et al. 2019b: 1011), fue una civitas stipendiaria -uno de esos parva oppida citados por Mela (3.4)- que conoció una intensa monumentalización desde la época del emperador $\mathrm{Au}-$ gusto -como, por otra parte, el resto de enclaves de su entorno, arriba citados (Andreu 2017 y Larrañaga 2007: 143-144)-, y que -como la mayor parte de las comunidades de su entorno- debió promocionar al estatuto de municipio de derecho latino en época flavia. Pese a que, todavía, carezcamos de mención epigráfica expresa de esa evolución institucional, esta resulta acorde, en cualquier caso, con la evolución urbanística que describe el enclave (Romero 2018: 201-206) y el que, sin duda, constituye, a día de hoy, su conjunto arquitectónico más representativo: el área meridional de su espacio forense.

En este contexto, el origen y desarrollo de Santa Criz como ciudad romana resulta incierto. Un pequeño castro de la Edad del Hierro ocupó el extremo noroeste del cerro del mismo nombre en las estribaciones de la sierra de San Pedro en territorio vascón 


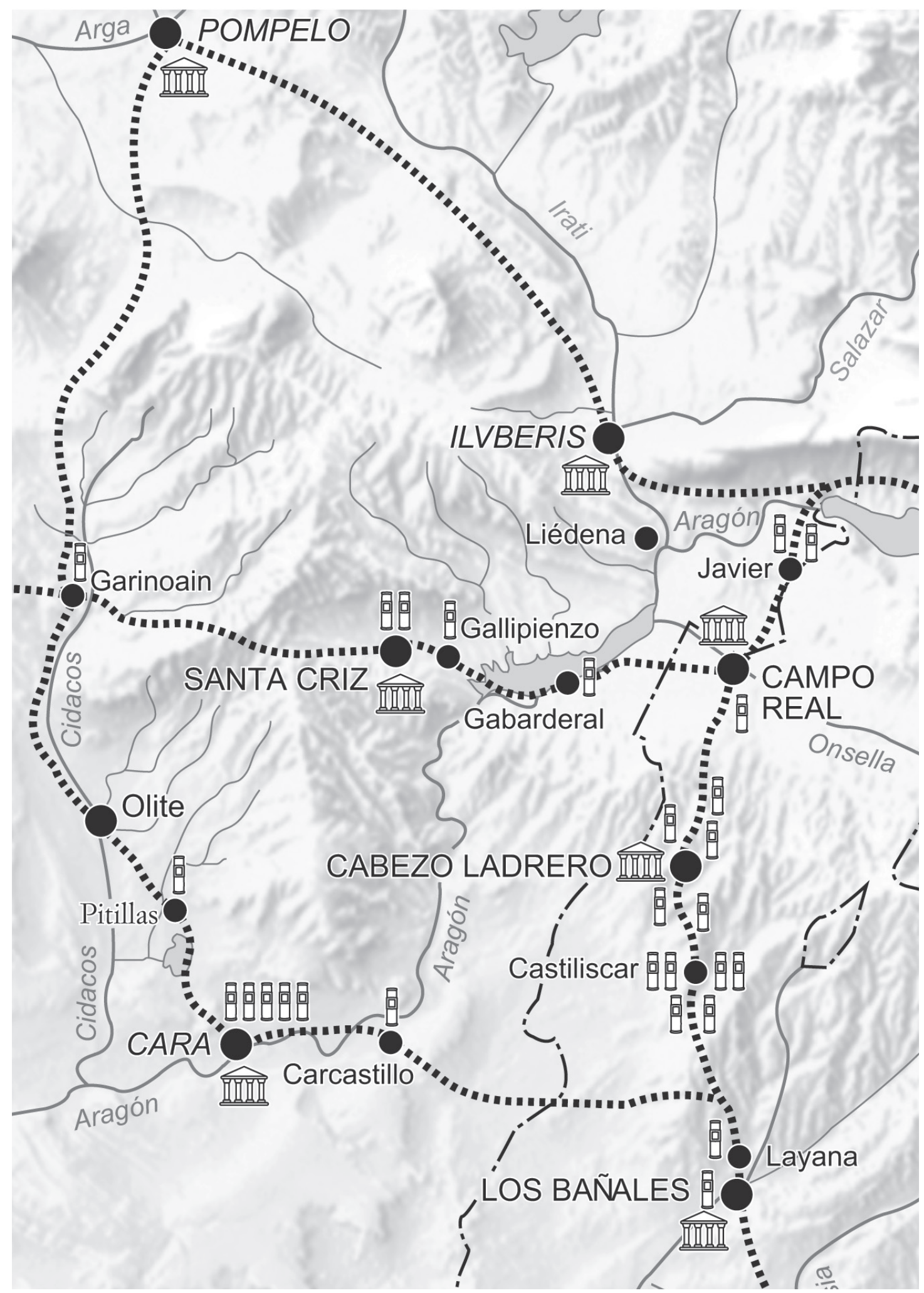

Figura 1. Situación de Santa Criz de Eslava en el entramado viario de época romana y ubicación de los centros urbanos de su entorno (mapa: Óscar Ribote a partir del topográfico nacional 1:50.000. Hoja Sangüesa). 


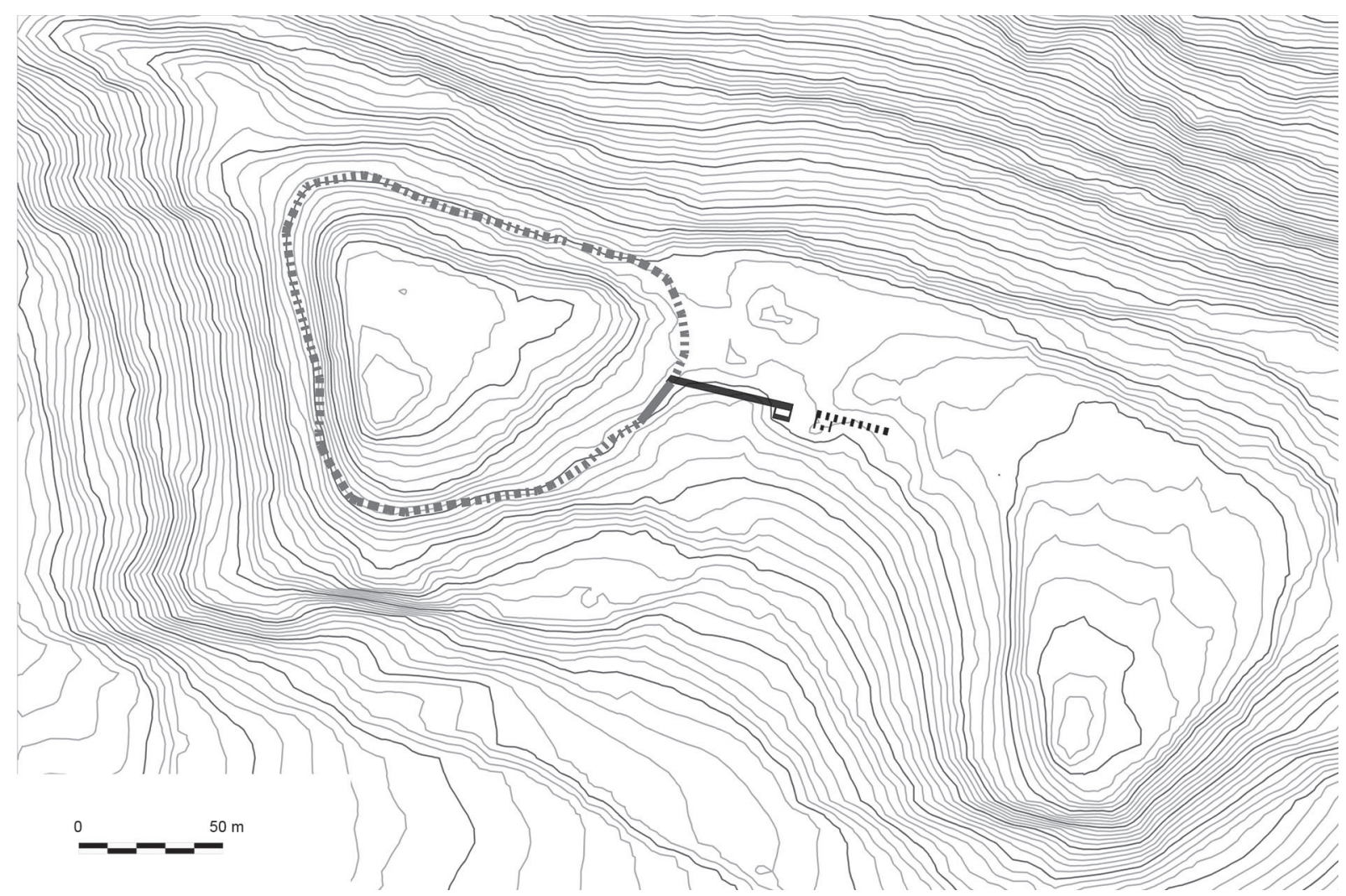

Figura 2. Fases previas a la monumentalización de la ciudad de Santa Criz de Eslava. En gris, la fase inicial correspondiente al castro de la Edad del Hierro; en negro, la fase de ampliación de la muralla en época tardorrepublicana (imagen: R. Cebrián sobre datos obtenidos de LIDAR IGN, hoja 0174 del PNOA MDT_05).

(Armendáriz 2008). Este primer asentamiento tuvo una extensión de 1,5 ha y contó con una muralla dispuesta a la cota 530 m s.n.m, que alcanzó una longitud de 400 $\mathrm{m}$. Se ha supuesto que el acceso a este recinto se realizó a través de una rampa, que recorre la muralla desde su flanco sur hasta llegar a la puerta situada en el lado noreste (Armendáriz 2008: 454-455). El lienzo de muralla oriental del castrum corresponde a la estructura identificada como GEM1 en las excavaciones desarrolladas entre 1995 y 2015 (Armendáriz et al. 2016: 3-4). Presenta una anchura de $3 \mathrm{~m}$ y se extiende a lo largo de 21,75 m. Cimentada sobre la roca natural, se construyó con grandes bloques trabados con barro y relleno interno de piedras de menor tamaño sin amalgamar.

La evolución urbana que hemos establecido a partir de la información reunida de los trabajos arqueológicos realizados revela nueve fases constructivas, que pueden agruparse en cinco grandes etapas. La primera etapa correspondería al castrum de la Edad del Hierro y la segunda a la ampliación del recinto murario cuando, previsiblemente, Santa Criz debió convertirse en un importante establecimiento urbano, vertebrador del fértil territorio del valle del río Indusi (Armendáriz 2008: 456) y en ese contexto de dignificación y monumentalización temprana que constituye una constante de los centros urbanos del entorno y aun de gran parte del Valle del Ebro (fig. 2).

Se edificó entonces un tramo rectilíneo de al menos 40,70 m de longitud, de dirección oeste-este adosado al ángulo sureste de la muralla anterior, que amplió notablemente las dimensiones de la población al ocupar la parte central del cerro de Santa Criz. En los trabajos arqueológicos recientes se equiparó este lienzo con una estructura de contención denominada GEM2 del espacio forense (Armendáriz et al. 2016: 248-249), aunque el análisis de sus características permite plantear la hipótesis de su adscripción al sistema defensivo. $\mathrm{Su}$ técnica constructiva, que ofrece una anchura variable entre 3 y 2,20 m, presenta un aparejo de piedra escuadrada en hileras regulares sin presencia de morteros. Para su construcción se realizaron dos muros paralelos, cuyo interior se rellenó con piedras de mediano y 


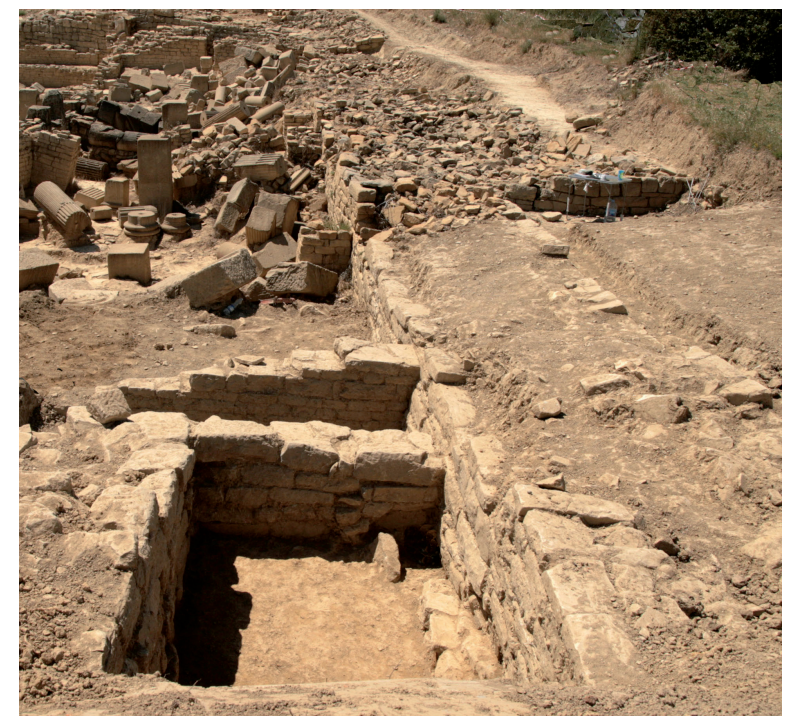

Figura 3. Vista general del tramo de muralla correspondiente a la ampliación del pomerium y torre (imagen: R. M $\mathrm{M}^{\mathrm{a}}$. Armendáriz y P. Sáez de Albéniz).

pequeño tamaño trabadas con tierra de textura arcillosa. Dispuso de una banqueta de cimentación sobre la roca natural reconocida en el extremo oriental de la muralla. En esta zona se ha documentado una torre de 6,14 $\mathrm{m}$ de longitud y 3,66 m de anchura, cuyos muros traban con el lienzo exterior de la muralla y presentan la misma fábrica. La excavación de los rellenos interiores de la torre solo aportó un nivel de amortización (UE 56) fechado en la segunda mitad del siglo I d.C. (fig. 3).

La construcción de la nueva muralla pudo conllevar el trazado de una vía de acceso a la población por el lado meridional del cerro, por la zona por la que discurrió el Camino Viejo de Gallipienzo paralelo a las viae sepulcrales detectadas en las excavaciones del área funeraria (Armendáriz et al. 2007). Sus restos parecen coincidir con la calle enlosada (UEC 1145) documentada delante de la torre, que asciende desde el oeste hasta alcanzar presumiblemente una puerta que, tal vez, estuvo flanqueada por dos torres iguales. Esta puerta quedaría anulada en la fase de monumentalización de la ciudad al construirse dos escaleras, una junto a este acceso, que permitirían la circulación directa a la plaza del foro.

La época augustea, clave en la puesta en relación de estas comunidades con el modo de vida romano (Andreu 2017), supuso el inicio de un proceso de transformación urbana y la construcción de su espacio público donde el forum reunió las funciones administrativojurídicas y un gran almacén aglutinó la actividad comercial (tercera etapa). La civitas alcanzaría entonces unas 13 ha de extensión. Este programa arquitectónico debió ser concebido en esa fecha tomando en consideración los materiales cerámicos contenidos en la estratigrafía del interior del criptopórtico, datados en el primer cuarto del siglo I d.C. (Armendáriz et al. 2016: 254), y la cronología aportada por el repertorio de piezas de decoración arquitectónica y escultórica exhumadas en los niveles de derrumbe del pórtico meridional y edificio circundante de la plaza por su costado occidental. Una reforma posterior condujo a la demolición del almacén público, que acabaría provocando en las décadas siguientes la realización de importantes obras de refuerzo y restauración del criptopórtico sur del foro para solucionar los problemas estructurales derivados de aquel desmontaje. Su abandono definitivo ha sido fechado en el siglo III con un antoniniano de Claudio II acuñado en Roma entre los años 268-270 d.C., que proporciona la fecha ante quem para el desplome del foro (Armendáriz et al. 2016: 255-256), quedando en su posición de caída un total de 149 piezas de decoración arquitectónica en el interior del criptopórtico y área occidental del almacén tras el colapso del foro. La aparición in situ durante el proceso de excavación de los fragmentos decorados constituye una de las imágenes más impactantes de la arqueología reciente en conjuntos forenses de Hispania.

La reocupación del espacio a partir del siglo IV se manifiesta en la construcción de varias estructuras murarias, que reutilizan sillares anteriores en sus fábricas, sobre los niveles de derrumbe del criptopórtico (cuarta etapa). Una torre bajomedieval situada en el área central del cerro constituye la última evidencia de su ocupación (quinta etapa).

\section{EL PROYECTO CONSTRUCTIVO. ACONDICIONAMIENTOS PREVIOS. LA FECHA DE CONSTRUCCIÓN}

Sin ninguna duda, las estructuras excavadas en Santa Criz corresponden al espacio público de la ciudad romana. El área urbanizada exhumada por los trabajos arqueológicos alcanzó los $1.150 \mathrm{~m}^{2}$ en el costado septentrional del espacio central del cerro y al exterior de la muralla. La posición topográfica de un lienzo de esta muralla sirvió como muro de contención delimitador de la plataforma ocupada por el foro, al que se adosó el criptopórtico excavado en la pendiente del cerro. Yuxtapuesto a él se construyó un gran almacén de carácter público. Ambas construcciones conformaron la fachada exterior del conjunto forense (fig. 4). 


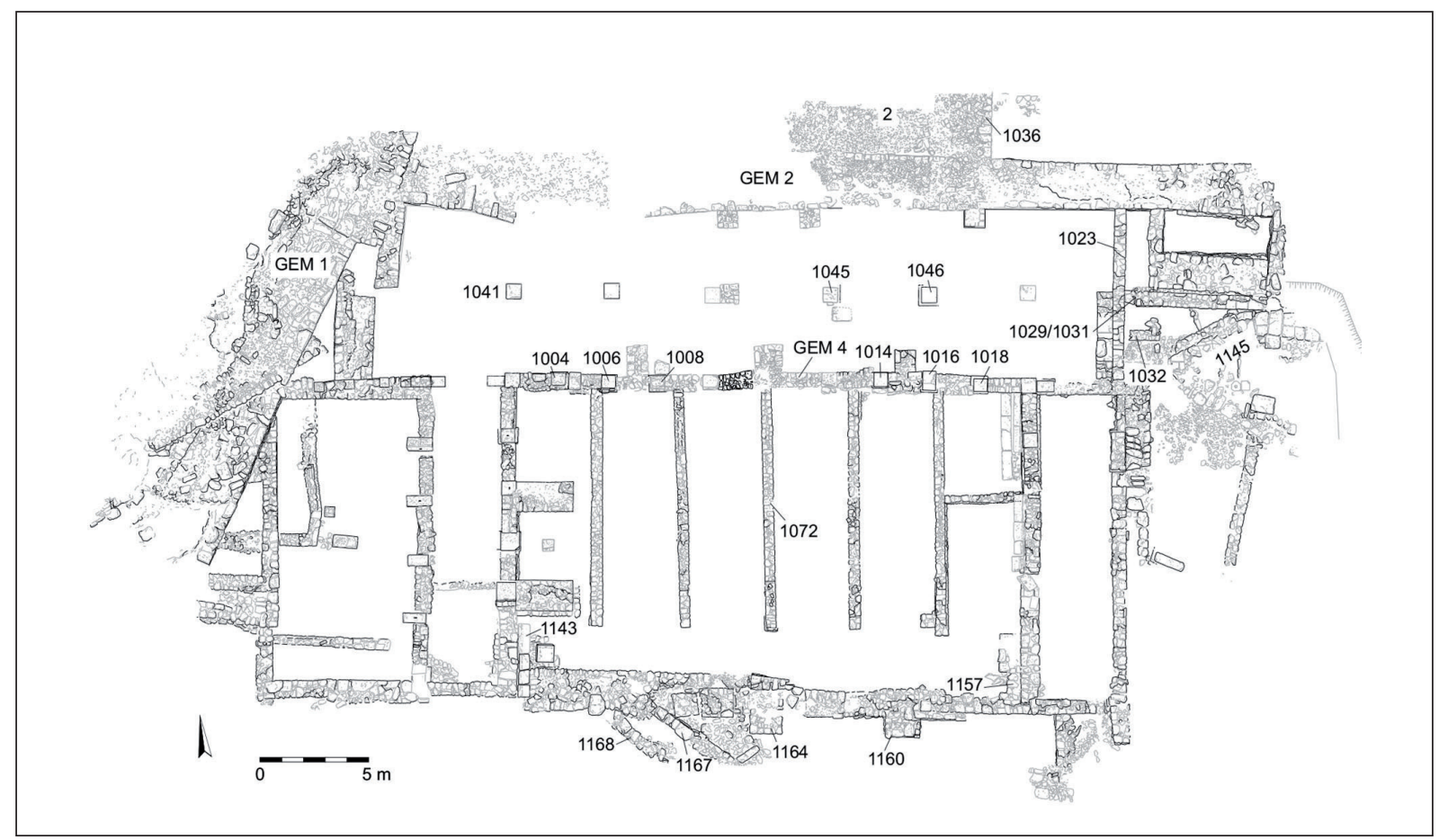

Figura 4. Planimetría general del conjunto excavado en Santa Criz de Eslava con la denominación de las UUEE mencionadas en el texto (I. Diéguez para Gobierno de Navarra).

La primera fase de la obra obligó a tallar la roca natural hasta la cota de 526,31 m s.n.m. Sobre esta superficie retallada se diseñó el nuevo espacio público que iba a quedar por debajo del nivel de la plaza forense. Se trazó un eje de simetría N-S coincidente con el centro de uno de los muros de las habitaciones del almacén (UEC 1072) y el intercolumnio central de los pilares del interior del criptopórtico. El módulo empleado fue de 81 pies de lado -aproximadamente $24 \mathrm{~m}$ - desde el eje, reservándose dos terceras partes para el almacén y una para el criptopórtico. Así, el conjunto construido al exterior de la muralla alcanzó los 162 pies de longitud y 81 pies de anchura, siendo el módulo de 27 pies aproximadamente $8 \mathrm{~m}$-del criptopórtico el que permite plantear una propuesta modular del foro.

En los trabajos arqueológicos llevados a cabo en el lugar no se alcanzó la cota de cimentación del criptopórtico en toda su extensión, pero los sondeos realizados evidencian que sobre la superficie nivelada se levantaron las estructuras murarias y se colocaron las zapatas de cimentación de los pilares centrales, vertiéndose sucesivas capas de áridos arcillosos, arenosos y paquetes de gravas (UE 66 y 75) a modo de rellenos constructivos. Estos paquetes están sellados por un nivel horizontal en el que se entremezclan manchas de cal y hogueras vinculadas a la actividad constructiva. Tampoco se documentaron zanjas de cimentación en los muros del almacén, aunque todos ellos presentan una banqueta en su base (fig. 5).

La disposición urbanística que adoptó el foro ganó superficie útil con la edificación del criptopórtico, destinado a elevar hasta la cota de la plaza una doble galería porticada por su costado meridional. Entre los trabajos de acondicionamiento previos se encontraba también la nivelación de la plaza consistente en un relleno de piedras (UEC 12) localizado junto al lienzo interior de la muralla. Este vertido constructivo colmató un retalle natural del terreno, que se extendía en una franja de $2 \mathrm{~m}$ de ancho y 17,5 $\mathrm{m}$ de longitud (Armendáriz et al. 2016: 248). Amortizó, al menos, una estructura adosada a la muralla (UEC 1036).

Todo el conjunto fue diseñado formando parte de un único programa arquitectónico realizado en los años de la monumentalización de la comunidad que habitaba Santa Criz. El establecimiento de la cronología debe abordarse con prudencia. Los materiales cerámicos obtenidos en la excavación son escasos y aportan una datación entre los siglos I a.C. y V d.C. El nivel previo a la construcción del criptopórtico ha sido fechado por las formas de terra sigillata itálica, barniz negro y 


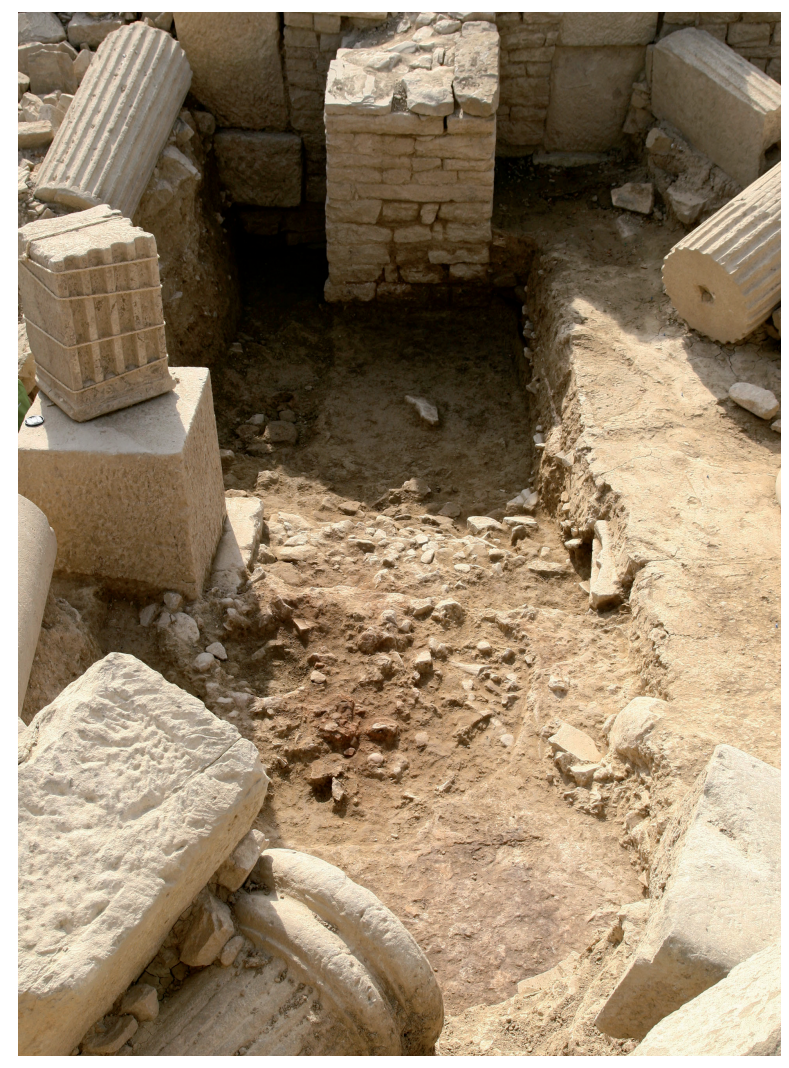

Figura 5. Relleno constructivo del criptopórtico y cimentación de uno de los pilares del interior del criptopórtico (imagen: R. $\mathrm{M}^{\mathrm{a}}$. Armendáriz y P. Sáez de Albéniz).

cerámica de tradición celtibérica en la segunda mitad del siglo I a.C. (Armendáriz et al. 2016: 253-254), constituyendo el terminus post quem para la construcción del foro. La nivelación de criptopórtico y almacén en la fase de reforma se realizó con un vertido muy homogéneo con abundante pintura mural y presencia de cerámicas residuales celtibéricas y producciones locales de cerámica común, junto a algunos fragmentos de terra sigillata hispánica lisa (Armendáriz et al. 2016: 263), de amplio marco temporal, que no ayudan a la hora de fijar la cronología del abandono. En el relleno de nivelación de la denominada taberna 1 (UE 101) se documentaron varios fragmentos de cerámica estampillada gris, de producción gala, junto a producciones del valle del Ebro de cerámica de paredes finas y vidrio. Su presencia obligaría a adelantar la fecha de amortización de esta habitación hacia el 350 d.C., entrando en contradicción con la datación flavia defendida hasta ahora. De manera que parece prioritario acometer el estudio ceramológico exhaustivo de los estratos excavados, que ayude en el establecimiento de la cronología de las fases arqueológicas identificadas. Esta tarea será abordada en el marco del proyecto de investigación en curso.

Hay que asumir además que las reformas posteriores enmascararon la planta original, de manera que muros que ahora están adscritos a la modificación del área excavada pueden estar cimentados sobre la fase original, tal y como se ha podido documentar en la UEM 4, que cerró el criptopórtico por el sur.

De manera que para determinar la datación del centro cívico monumental contamos con la identificación de la técnica constructiva empleada-opus vittatum, formado por piedras de tendencia rectangular y mediano tamaño dispuestas en hiladas regulares y bien aparejadas- y las características particulares de los elementos arquitectónicos utilizados en su decoración.

La nueva decoración arquitectónica -como toda la obra del conjunto- fue ejecutada en arenisca local -de la que se consignan afloramientos con marcas de extracción de probable filiación romana en toda el área de Artamaleta, al oeste del cerro de Santa Criz-y, por tanto, elaborada por un taller local en el que tal vez intervinieron artesanos itinerantes (Mar y Pensabene 2013: 2730). El origen de los elementos decorados no es único, reconociéndose distintos órdenes arquitectónicos, así como abundantes marcas del proceso constructivo. El estilo de algunos capiteles de orden corintio procede de los modelos estilísticos del Segundo Triunvirato, que perduró en Hispania durante el reinado de Augusto (Heilmeyer 1970: 39, Trunk 2008: 21-24). Los capiteles del orden dórico/toscano de la porticus duplex del foro presentan el perfil del equino en arco de círculo, seguido de un caveto y sumoscapo liso con ejemplos en el período augusteo en Ampurias (Aquilué et al. 1984: 85) e Italica (Rodríguez Gutiérrez 2004: 450-451).

Aépoca de Augusto remite también el material escultórico recuperado de los estratos de derrumbe hallados en el interior del criptopórtico. La estatua más completa se adscribe al tipo Ba de H. R. Goette (1990: 113-129), definido por la toga en forma de U característica de los inicios del siglo I d.C. (Romero 2018: 208-209 y Andreu et al. 2019a: 38-54).

\section{LA ARQUITECTURA DE LAS ESTRUCTURAS EXHUMADAS}

\subsection{El criptopórtico del foro y el almacén público}

El complejo excavado corresponde a un criptopórtico que sirvió de cimiento de la porticus duplex delimitadora de la plaza del foro por su costado meridional. 


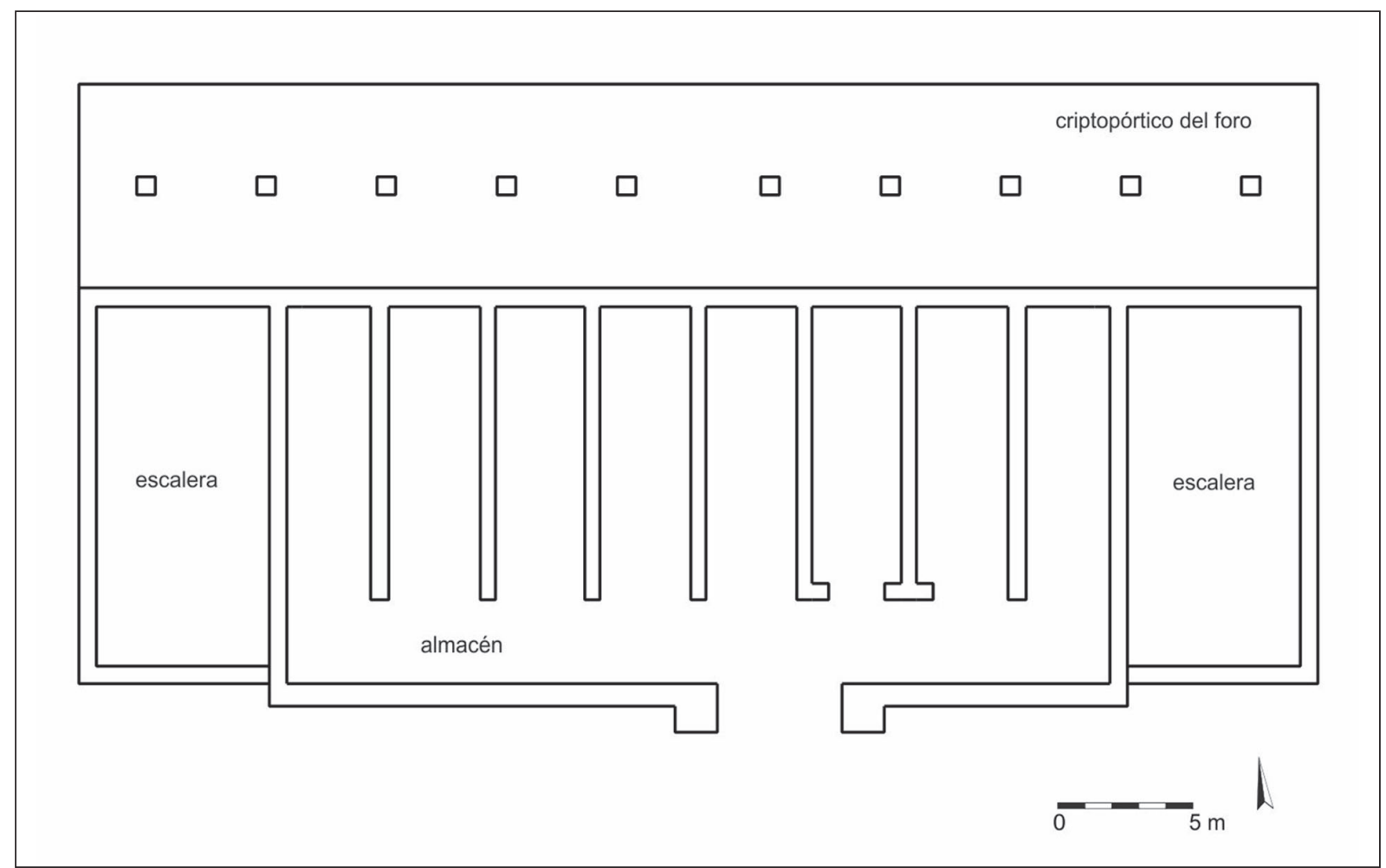

Figura 6. Restitución de la planta del criptopórtico sur del foro y el almacén de Santa Criz de Eslava, a partir de la documentación publicada de los resultados de la investigación arqueológica de Arméndariz et al. 2006.

Dentro de la tipología establecida por E. M. Luschin (2002: 32-33), el criptopórtico de Santa Criz se adscribe al modelo con subestructuras en forma de corredor en complejos aterrazados. En la trasera del muro sur del criptopórtico se adosó un edificio conformado por grandes naves rectangulares, organizadas en hilera y abiertas a un corredor longitudinal de acceso, interpretado como almacén. Esta disposición conforma un espacio arquitectónico público en dos terrazas: la superior, al norte, con la plaza y edificios del foro de la ciudad, aun por excavar, y la inferior, al sur, con un establecimiento destinado al almacenamiento de productos y centralizador de las tasas agrícolas que debieron constituir la base económica de la civitas (fig. 6).

Quedan inciertas las estructuras exhumadas en el costado oriental de este conjunto, donde se disponen dos paramentos de opus vittatum con orientación E-O (UEC 1029/1031 y 1032). Ambos están cortados por el muro UEC 1023, que acotó el criptopórtico por su lado oriental, dejando abierta la posibilidad de que en su fase inicial la subestructura presentase una longitud mayor, tomando en consideración por un lado la disposición de la UEC 1029 en el eje de los pilares centrales y por otro, la técnica constructiva de la UEC 1023 idéntica a la empleada en los muros adscritos a la reforma posterior.

El criptopórtico en su estado actual presenta planta rectangular y está orientado E-O. Ocupa un espacio de unos $300 \mathrm{~m}^{2}$. La longitud máxima es de 38,40 m y 8,19 $\mathrm{m}$ de anchura. Su altura alcanzó los 3,30 m. Los límites $\mathrm{N}$ y $\mathrm{O}$ del criptopórtico corresponden al tramo de muralla GEM 2 y al lienzo murario del castrum GEM 1, respectivamente. Por el este, cierra el recinto un paramento con obra de mampostería careada trabada con tierra arcillosa (UEC 1023), de 0,55 m de anchura. Por el sur, la pared está realizada en aparejo mixto que combina cadenas de opus quadratum con paños de opus vittatum, también amalgamados con barro (GEM 4). Las cuatro hiladas verticales de sillería en seco sirvieron para proporcionar la solidez necesaria a la estructura, diseñada como muro de cierre por el lado sur del foro. Los sillares presentan almohadillado por ambas caras y miden $0,68 \times 0,68 \mathrm{~m}$, trabando con los lienzos de sillarejo, de $0,55 \mathrm{~m}$ de anchura. La distancia entre ejes de los pilares 1-2 y 3-4 es de 9,13 m y de 7,77 m entre los pilares 2-3. 
En el interior del criptopórtico se sitúa una línea de seis basamentos cuadrados, que apoya en sillares de cimentación de $0,95 \mathrm{~m}$ de lado, a los que se llegó en excavación en dos de los pilares (UUEE 1045-1046). Están conformados con bloques escuadrados de diferentes alturas y sección ligeramente troncopiramidal. La superficie de cada una de las caras presenta huellas muy marcadas del trabajo de la piedra y aristas cinceladas. En el lado occidental, siguiendo el ritmo de los pilares centrales deben situarse otros dos, uno debajo la UEC 1041 y otro bajo el derrumbe de los elementos arquitectónicos, que no ha sido excavado.

Los pilares interiores del criptopórtico presentan una disposición irregular respecto a su eje de colocación y tampoco la distancia entre ejes guarda un ritmo regular. Por término medio, distan aproximadamente 4,50-4,65 m, con la excepción de los basamentos centrales conservados donde se separan 5,45 m. Sirvieron para sostener las vigas del forjado del piso superior y para la cimentación de las columnas del porticado interior del foro.

La subestructura se construyó con la finalidad de disponer de más terreno en plano horizontal del espacio destinado a la plaza pública, que se desarrolló en la terraza superior. La solución adoptada fue frecuente en la arquitectura romana para nivelar y ampliar el espacio disponible, tomada de la experiencia helenística (Gros 1996: 95-99). Sobre el criptopórtico de Santa Criz se situó una doble galería porticada, de 3,80 m de anchura cada una, a la que pueden adscribirse algunos de los elementos arquitectónicos recuperados en los niveles de derrumbe (UUEE 4 y 6), atribuibles al orden dórico/toscano.

El criptopórtico presenta defectos constructivos de origen, tales como las irregularidades de la puesta en obra de los pilares interiores, la estrechez del muro de cierre oriental y sobre todo el meridional, que pudo ser corregida con la inserción de un número mayor de cadena de sillares. Estas deficiencias estructurales abocarían a la edificación a su colapso, tal y como se produjo a inicios del siglo III d.C. a pesar de las obras de refuerzo llevadas a cabo a finales del siglo I, cuando se desmanteló el almacén debilitando su estructura. No hay evidencias de una cubierta con bóveda a modo de los criptopórticos de las ciudades itálicas del Lacio (Giuliani 1973), Campania (Johannowsky 1973) o de la Galia, como el de Arles (Amy 1973), fechados en época tardorrepublicana y augustea. En cambio, se ha podido atestiguar la existencia de una techumbre plana conformada por vigas de madera a partir de las entalladuras conservadas en algunos de los sillares aparecidos en el derrumbe, que sirvieron para el asiento de los soportes del forjado.
Formando parte del mismo proyecto constructivo que el foro de la ciudad, se levantó un edificio de planta rectangular, que recorrió su frente meridional. Este edificio fue identificado con un horreum (Armendáriz et al. 2016: 263-265). La tipología de los espacios de almacenaje destinados a la conservación de variadas mercancías antes de su distribución y/o comercialización fue establecida por G. Rickman (1971). En líneas generales, diferenció dos tipos: aquellos que presentan grandes naves alineadas en fila simple o doble y edificios de patio central. A la primera categoría puede adscribirse el almacén de Santa Criz. Junto a la arquitectura del edificio, el hallazgo en excavación de fragmentos de dolia y recipientes anfóricos, entre los que se han identificado ánforas del área bética destinadas al suministro de salazones y ánforas vinarias de origen tarraconense, determina su función. Respecto del carácter público de este espacio, puede recordarse aquí -como se ha hecho recientemente (Armendáriz et al. 2016: 264) - la presencia de un dispensator publicus en la ciudad, encargado entre otras funciones de la gestión de préstamos y cobros de una caja pública (Andreu 2010), si bien la complejidad de la vida municipal no excluye que este Athenio -al que conocemos por el homenaje de su compañera, Ant(onia) Crysaeis sobre una placa de circunstancias y lugar de hallazgos poco claros (Andreu et al. 2019b: 29$32, n^{\circ} 3$ )- desempeñase en la comunidad otras tareas ajenas -o complementarias - a la gestión del almacén. En cualquier caso, Ahtenio debió estar bajo las órdenes de los cuestores municipales (Rodríguez Neila 1997: 226). $\mathrm{Su}$ presencia manifiesta, por un lado, la existencia de un ordo decurionum en Santa Criz a partir del siglo I d.C. fecha que se propone para la inscripción, a pesar de que el repertorio epigráfico procedente del lugar no ha documentado hasta el momento mención alguna al cursus honorum de las magistraturas civiles- $\mathrm{y}$, por otro, el control público de las mercancías depositadas en el almacén.

Ese almacén presenta unas dimensiones máximas conservadas de $32,15 \mathrm{~m}$ de longitud y $15,70 \mathrm{~m}$ de anchura (fig. 7). Su espacio interior está compartimentado en ocho naves paralelas orientadas N-S, que miden 11,25 $\mathrm{m}$ de longitud y aproximadamente 3,50 $\mathrm{m}$ de anchura. Por el lado occidental presenta un cuerpo anexo, de 7,50 $\mathrm{m}$ de anchura, subdividido por muros transversales, que interpretamos como una caja de escaleras de acceso directo a la plaza del foro desde la calle situada al sur.

La entrada al almacén se realizó desde el lado meridional a través de un corredor de 2,70 m de anchura, que comunicaba con todos los compartimentos. La entrada a las cellae de los extremos oriental y occidental debió realizarse a través de puertas ubicadas en los 


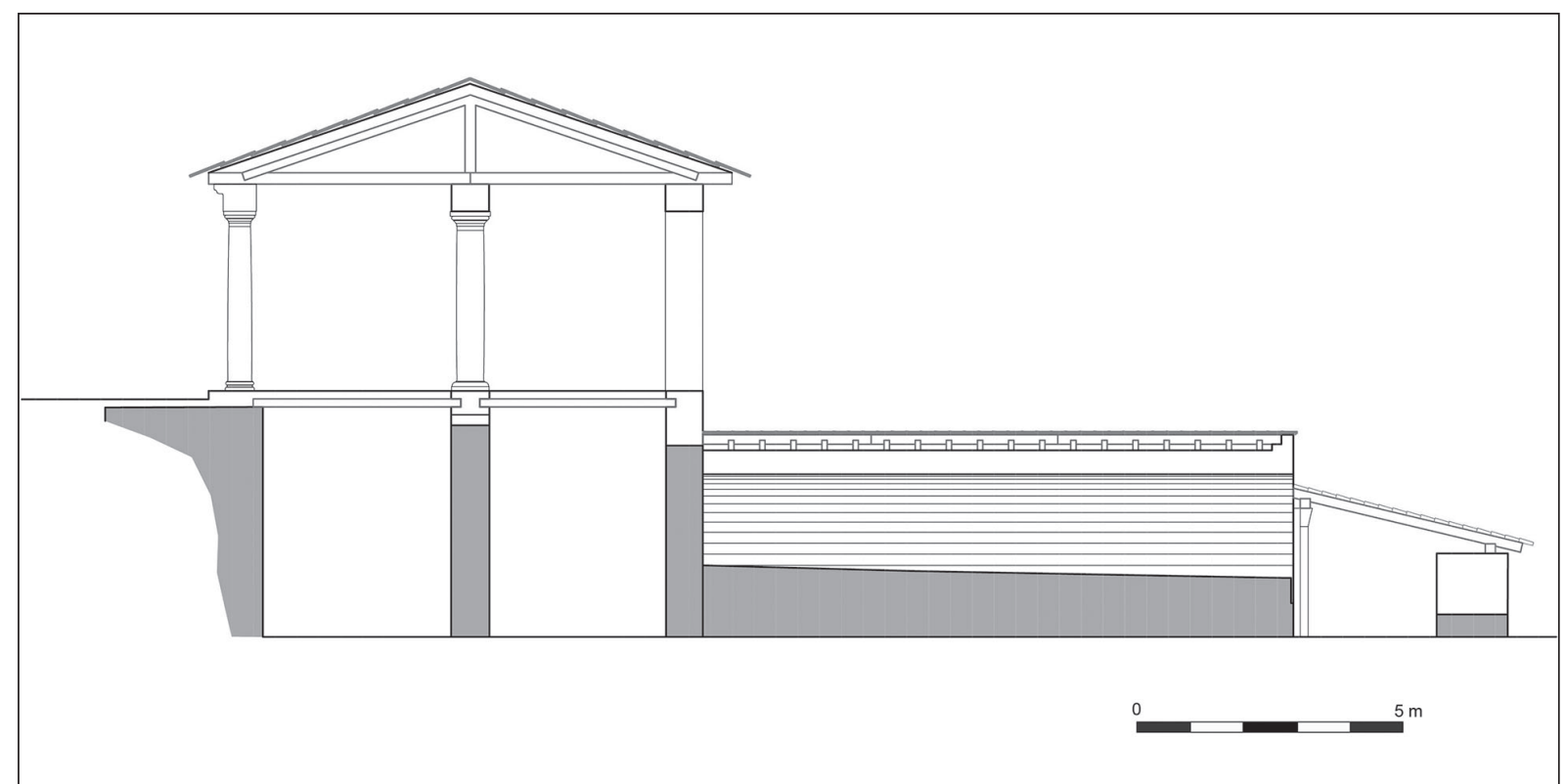

Figura 7. Propuesta interpretativa de la sección del pórtico meridional del foro y almacén público de Santa Criz de Eslava (imagen: I. Hortelano).

muros N-S. Ciertos restos podrían corresponder a la cimentación de varios peldaños (UUEE 1143 y 1157), que hacen pensar que se situaban a un nivel más elevado que el corredor.

A este corredor se accedía desde una única puerta que parece reconocerse en el muro de cierre del edificio. La puerta tiene un vano de 4,65 m y está flanqueada por dos machones de obra (UUEE 1160 y 1164). Su jamba izquierda coincide con el eje axial del proyecto constructivo. Por debajo de este muro atraviesa un canal de desagüe en dirección noroeste-sureste siguiendo la pendiente del cerro. Debió formar parte del sistema de drenaje del almacén y está construido con dos muros de mampostería careada (UUEE 1167-1168), de 0,55 m de anchura, que delimitan un canal de $1,10 \mathrm{~m}$ de anchura. Los muros perimetrales del edificio presentan paramentos de opus vittatum sin argamasas. La anchura del muro oriental y occidental es de $0,65 \mathrm{~m}$ y de $1,30 \mathrm{~m}$ en el muro meridional. Esta diferencia de grosores debe relacionarse con la necesidad de robustecer la fábrica del muro sur, dada la longitud de su traza y el hecho de que esté construido en la ladera sin contar con el refuerzo de ninguna otra estructura, mientras los muros este y oeste soportarían los esfuerzos laterales del posible sistema de bóvedas.

Las paredes de las naves se adosaron al muro de cierre del criptopórtico por su costado sur (GEM 4). Se trata de muros de sillarejo, de 0,45-0,50 m de anchura, que conservan una pequeña zapata de cimentación.
Las habitaciones situadas en el lado meridional presentan la entrada enmarcada por dos salientes de sillarejo, de 0,60 $\mathrm{m}$ de anchura, definiendo un acceso de aproximadamente $2 \mathrm{~m}$. En cuanto a su decoración, el hallazgo de dos fragmentos de fustes de semicolumnas lisas (UUEE 790 y 791), de 0,42 y 0,43 m de anchura respectivamente, en una de las naves y en el nivel de amortización del edificio (UE 787) permite restituir su ubicación, adosados al extremo de los muros de la nave, flanqueando la puerta de acceso. En el mismo estrato se halló un conjunto de lajas de piedra en posición vertical (UE 788), que evidencia el uso de tejas de piedra de las naves del almacén (fig. 8).

Aunque el área interior del edificio no ha sido excavada completamente, en algunos de los departamentos (UE 792) se documentó un nivel muy disgregado con presencia de cantos de río, de $0,10 \mathrm{~m}$ de potencia, que podría interpretarse como los restos de un pavimento de mortero de cal.

\subsection{Evidencias de la estructura portante sobre vigas del criptopórtico y tejado del pórtico sur del foro}

Entre el material arquitectónico recuperado en la excavación del derrumbe del pórtico y edificio circundante de la plaza del foro por su costado occidental, se encuentra 


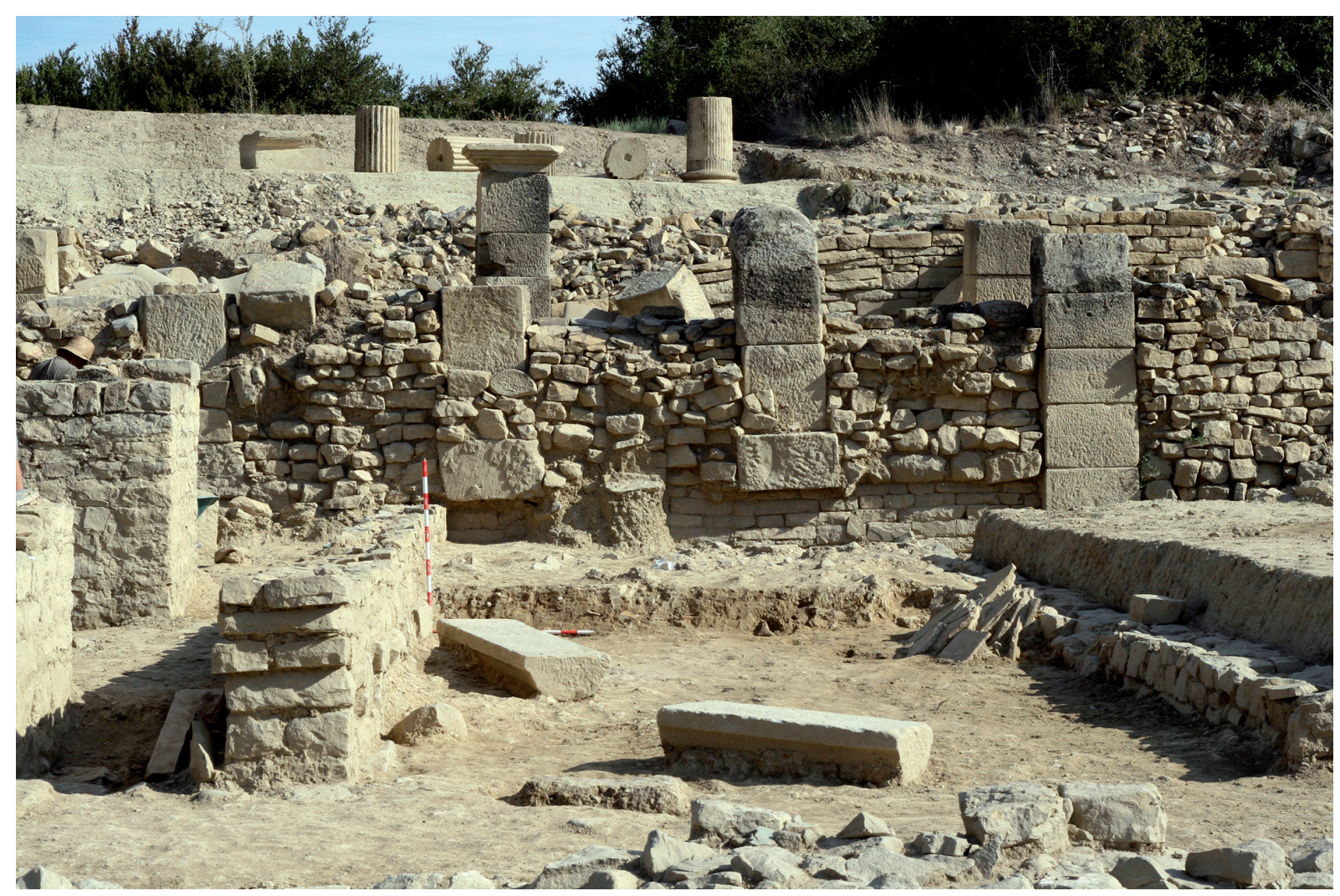

Figura 8. Vista desde el sur de una de las naves del almacén con la posición en la que se encontraron las semicolumnas que flanquearon la puerta de acceso y las lajas de piedra del tejado. Al fondo, el muro de cierre del criptopórtico GEM 4 (imagen: R. Mateo).

un conjunto de dieciocho piezas que define el sistema de forjado de la subestructura y las particularidades del tejado del pórtico situado en el piso superior. Algunas de ellas conservan además muescas en la cara superior y laterales para el izado con grúa en la puesta en obra.

Sobre los sillares superiores de los pilares del interior del criptopórtico corrían pares de vigas que los unían axialmente en sentido longitudinal. Arrancaban desde los muros de cierre este y oeste de la subestructura. Una de las piezas halladas es un sillar cuadrangular, de 0,55 $\mathrm{m}$ de lado y $0,47 \mathrm{~m}$ de altura, que presenta dos entalladuras en la misma dirección en la parte inferior de una de sus caras laterales. Miden 0,27 x 0,35 x 0,14 m y sirvieron para el encaje de estas jácenas del forjado estructural del criptopórtico. Esta pieza resulta muy significativa, pues permite restituir el orden del pórtico meridional del foro al tener tallada en su cara superior una basa toscana sin plinto, de $0,43 \mathrm{~m}$ de diámetro del fuste (fig. 9.1).

Sobre las jácenas y los muros norte y sur de la estructura, apoyaron sucesivas vigas transversales separadas entre sí $0,46 \mathrm{~m}$. La evidencia arqueológica se encuentra en cuatro sillares pertenecientes a los pilares del interior del criptopórtico, que disponen de dos entalladuras enfrentadas en sus caras laterales, de 0,16 m de profundidad (fig. 9.2, 9.3 y 9.4). En ellas se encajarían vigas de $0,13 \mathrm{~m}$ de canto. Tres de los sillares presentan planta cuadrangular, de $0,65 \mathrm{~m}$ de lado, mientras el cuarto mide $0,70 \times 0,64 \mathrm{~m}$. La separación entre ellas se deduce del hallazgo de un sillar de $1,11 \mathrm{~m}$ de longitud, 0,50 $\mathrm{m}$ de anchura y 0,39 $\mathrm{m}$ de altura, que debió situarse en uno de los dos muros largos al nivel del forjado, posiblemente en el meridional atendiendo a la posición de caída de la pieza en el momento del derrumbe (fig. 9.5). Presenta dos muescas separadas $0,46 \mathrm{~m}$, medida que corresponde al entrevigado. Con esta función, se ha documentado otro fragmento de sillar que conserva una entalladura de las mismas dimensiones. Finalmente, estas vigas servirían para el apoyo de los travesaños a los que se fijaría el tablero del encofrado del suelo del piso superior.

Al mismo sistema de entrevigado se adscriben otros dos sillares cuadrangulares, de $0,55 \mathrm{~m}$ de lado, que también presentan un rebaje para el asiento de vigas de 0,13 

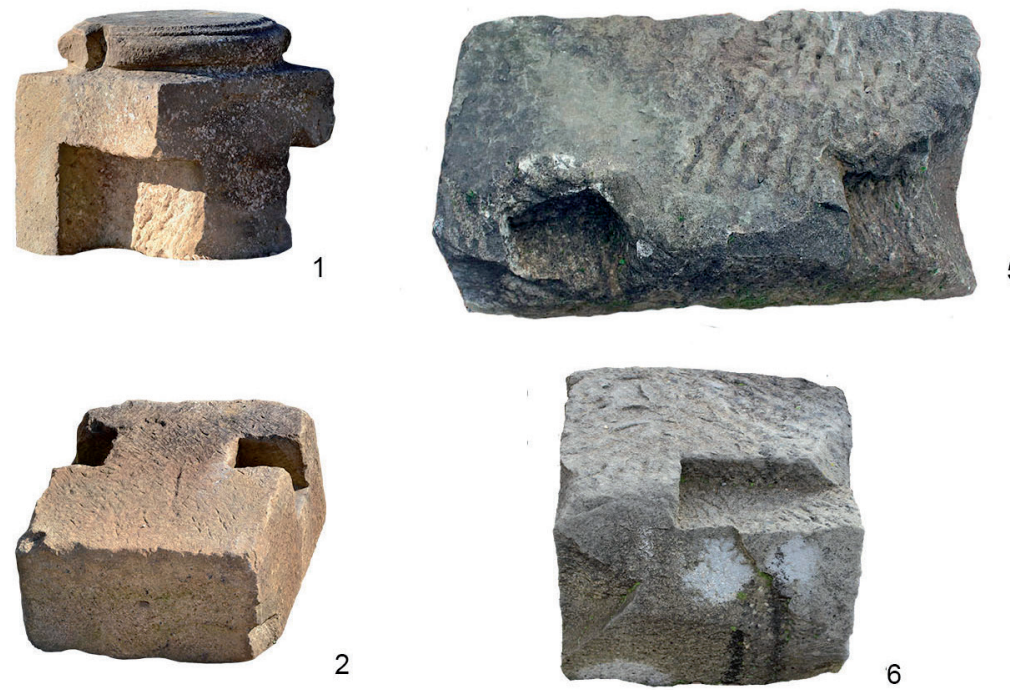

5

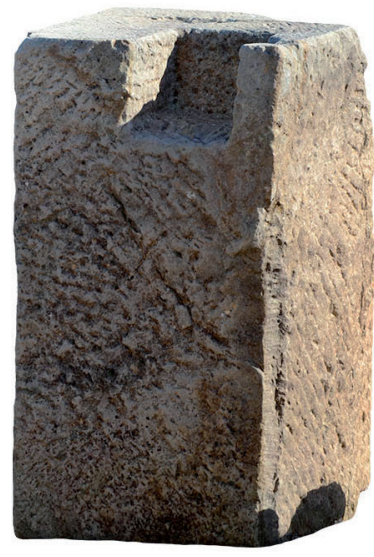

8

6

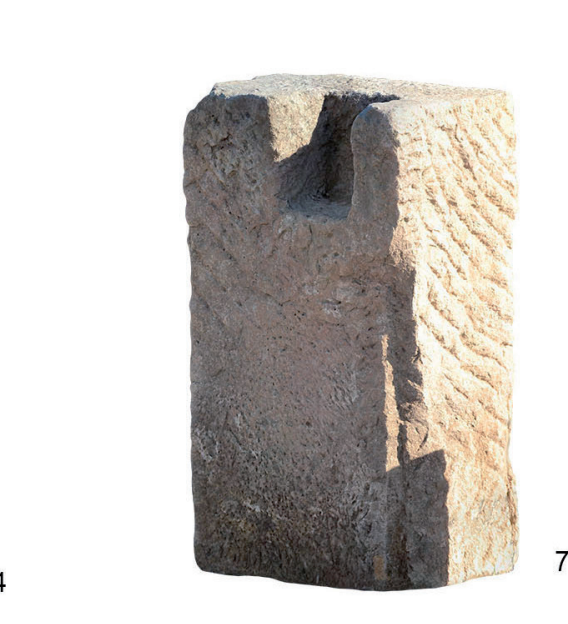

7

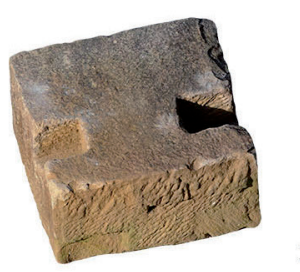

3

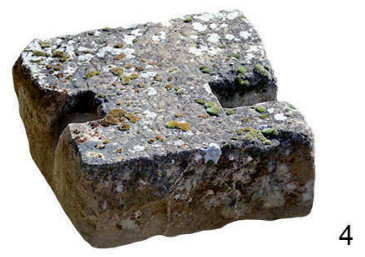

4
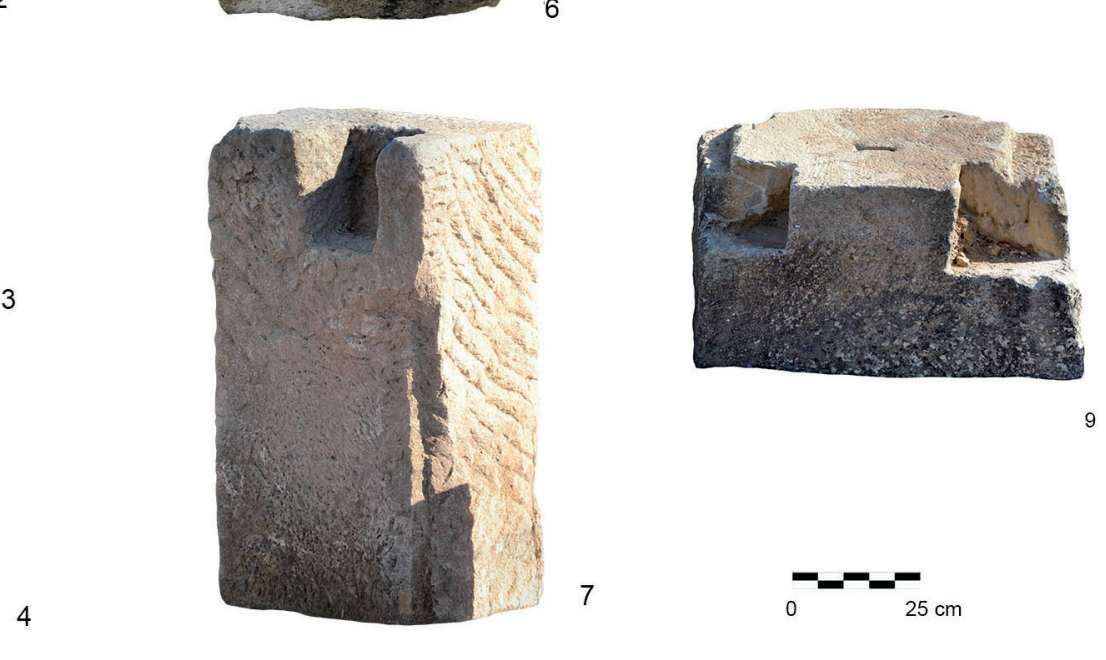

9

Figura 9. Vistas fotogramétricas de los elementos arquitectónicos atribuibles a la estructura portante sobre vigas del criptopórtico meridional del foro de Santa Criz. Advertimos de que las piezas $n^{\circ} .2,3$ y 4 no muestran su altura original debido a la ubicación en la que se encuentran actualmente (imagen: R. Cebrián).

$\mathrm{m}$ de canto. El tamaño de las piezas aconseja considerar su disposición en el lienzo meridional de cierre del criptopórtico (fig. 9.6).

La remodelación del espacio acaecida a finales del siglo I conllevó inmediatamente después el refuerzo de la estructura del criptopórtico. Entre las acciones realizadas, se encontraba la instalación de seis machones o pilares de sillería en su muro meridional con el fin de robustecerlo en los puntos en que la construcción soportaba mayor empuje (UEC 1004, 1006, 1008, 1014, 1016 y 1018). Se trataba de colocar cadenas de sillares dispuestos verticalmente, asentados sobre otros bloques a modo de banquetas de cimentación. Dos de ellos conservan una entalladura idéntica en la cara superior, de $0,25 \times 0,22 \times 0,20-0,26 \mathrm{~m}$, para el apoyo de las vigas transversales. La talla de los sillares con un desbastado tosco y huellas del instrumental empleado muy marcadas permite su atribución a esta fase de reforma (fig. 9.7 y 9.8). A este periodo adscribimos también un sillar que presenta dos muescas realizadas en la misma cara lateral para el cobijo de jácenas de 0,24-0,20 m de canto. La pieza mide $0,48 \times 0,74 \times 0,54 \mathrm{~m}$ y presenta en la cara superior dos rebajes, de $0,8-0,10 \mathrm{~m}$ de profundidad, quizás para el apoyo de las siguientes vigas (fig. 9.9). 


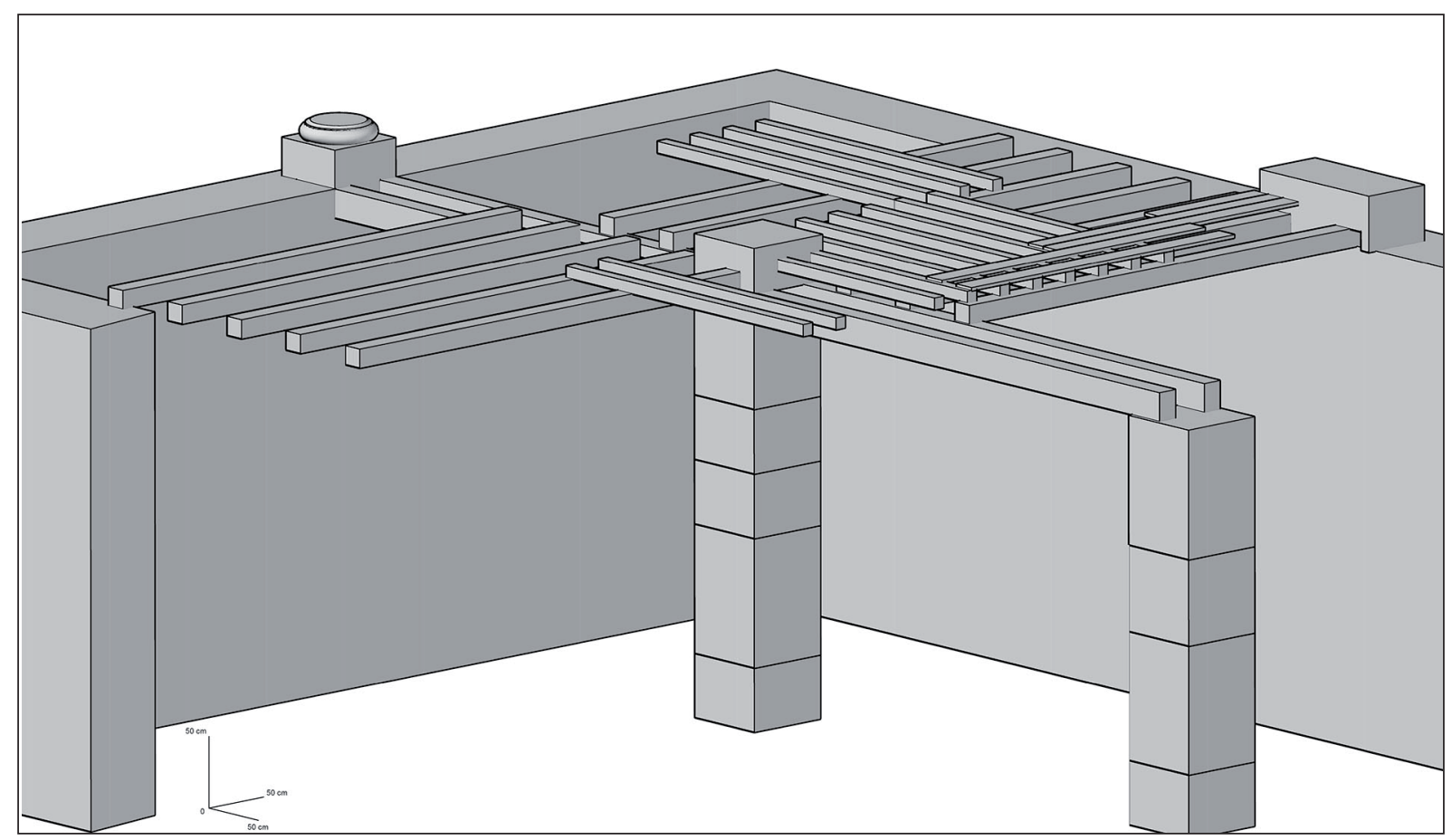

Figura 10. Propuesta de reconstrucción del forjado del piso del pórtico meridional del foro de Santa Criz (imagen: I. Hortelano).

Es posible que el refuerzo del criptopórtico incluyese la instalación de traviesas que atasen los nuevos pilares levantados en el muro meridional con los centrales.

De esta manera, el piso del pórtico meridional del foro se asentaba en un forjado cuyo espesor total superaría los 0,50 $\mathrm{m}$, conformado con vigas de madera colocadas longitudinalmente de pilar a pilar que corrían por la parte central del criptopórtico. Sobre ellas apoyaban otras vigas transversales, que partían desde el muro norte -muralla- hasta los pilares centrales y desde estos al muro meridional. Esta estructura servía para el apoyo de las latas y tablero sobre los que se construiría el suelo del pórtico (fig. 10). Un sistema idéntico lo encontramos en el forjado del criptopórtico de Conimbriga, reformado en época flavia y restituido a partir del texto de Vitruvio (Alarcão y Etienne 1973: 403, fig. 11).

Del mismo derrumbe proceden cuatro piezas, cuyas posiciones de caída y características formales sugieren su ubicación en el tejado del pórtico del foro (ESL1/71, 106, 122 y $\sin \mathrm{n}^{\circ}$ inv.). Se trata de lastras, de $0,22 \mathrm{~m}$ de altura, que presentan secciones en su cara superior talladas en bisel, conformando un ángulo de $20^{\circ} / 21^{\circ}$. La distancia entre la sección rebajada y la que no lo está es de 0,49 m. El espesor es de 0,62 m.

La cubierta del pórtico del foro debió realizarse con tejas de piedra, tomando en consideración la inexistencia en el nivel de derrumbe de material latericio asignable a tegulae e imbrices y la descripción de la composición de este derribo, donde se identifican «pequeñas piedras y lajitas que se estiman producto de la degradación de posibles lajas de cubierta» (Armendáriz et al. 2016: 255). Sin duda, constituye una particularidad constructiva del foro, que puede responder a una tradición indígena. No hemos encontrado ningún paralelo para este tipo de pieza, que consideramos una singularidad relacionada con el material pétreo empleado en el tejado (fig. 11).

Los sistemas de cubierta de la carpintería de madera del tejado pudieron realizarse con tejas de arcilla, en piedra utilizando losas o placas y, excepcionalmente, en opus caementicium (Ginouvès 1992: 182-183). En el mundo griego, las tejas en piedra en forma de losanges o triangulares fueron empleadas en la cubierta de edificios circulares como el tholos del Ágora de Atenas (Hellmann 2002: 320-326). Fueron frecuentes las tejas de mármol en los edificios religiosos, encontrando ejemplos en Grecia, Magna Grecia, Anatolia e incluso en la península ibérica en el templo ampuritano de Asclepios (Aquilué et al. 2001: 37) o en el Traianeum de Italica (Vargas 2018: 215-222). Esta tradición de cubierta en piedra fue asimilada por Roma, difundiéndose principalmente en la arquitectura funeraria (Adam 1989: 232). El 


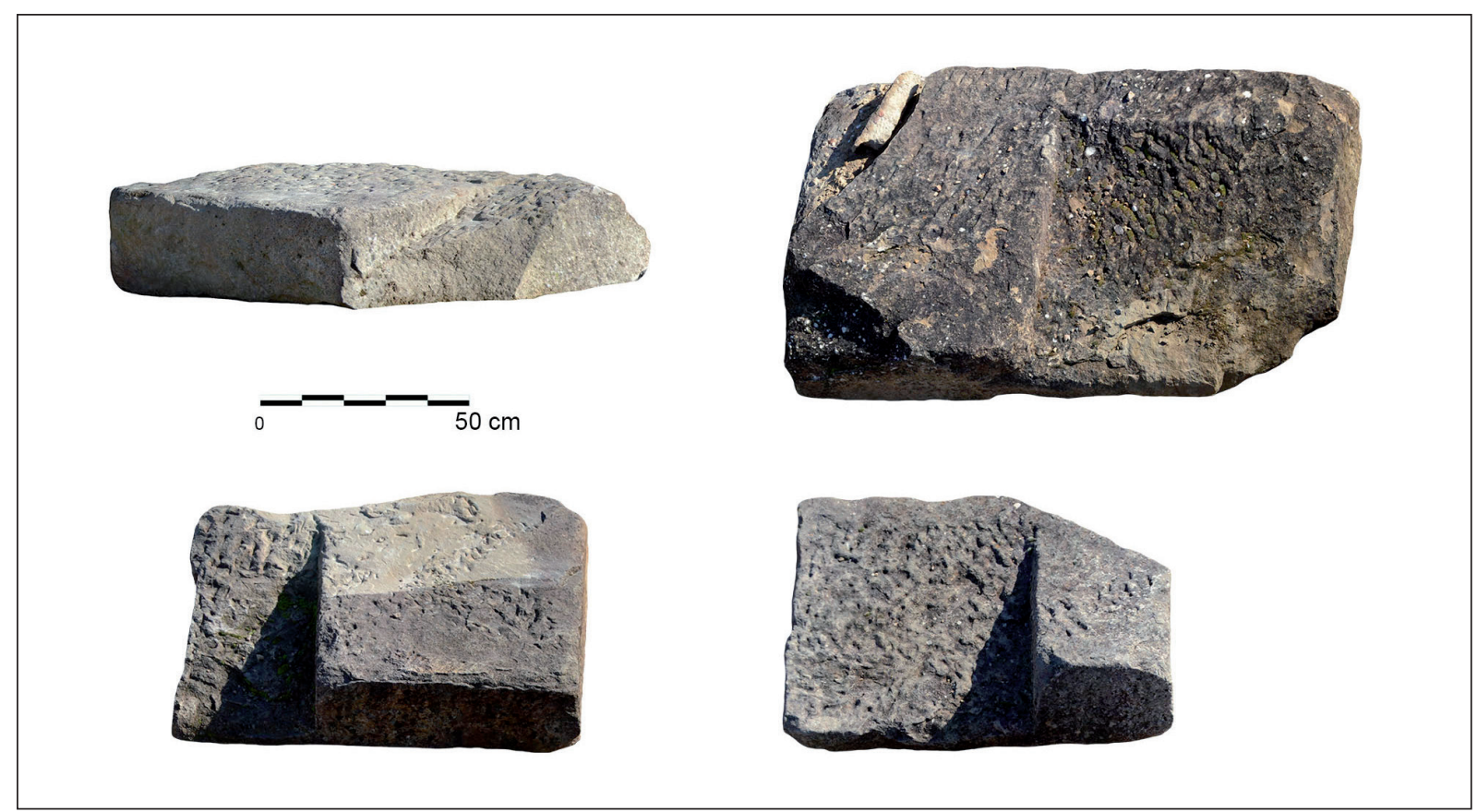

Figura 11. Losas de piedra de apoyo de la cubierta y del soporte del alero del tejado del pórtico sur del foro halladas en el derrumbe del interior del criptopórtico (imagen: R. Cebrián).

sistema de tejas conformadas con losas cortadas con sierra fue muy utilizado en Galia. Están presentes en numerosos oppida del área marsellesa (Excoffon 2009: 265). En Glanum el tipo de cubierta en piedra se ha reconocido en un templo próstilo de tipo toscano datado en el siglo II a.C. y ubicado en el foro (Roth-Congès 1992: 356, fig. 2, XVII), que fue identificado, estudiado y restituido por A. Olivier (1982). Y en Olbia, tejas de piedra de un tejado tipo corintio se vinculan a un posible santuario fechado a inicios del siglo II a.C. (Excoffon 2009). Los hallazgos más tardíos se fechan en el siglo II d.C., aunque se trata del reempleo de tejas de piedra (Poguet y Pelletier 2004: 111). A escala regional, esta praxis para las cubiertas también se ha anotado como plausible en el vecino yacimiento de Campo Real/Fillera, en Sos del Rey Católico, conectado con la civitas de Santa Criz de Eslava. En él, y en prospecciones superficiales, la ausencia de tegulae e imbrices y la presencia constante de lajas de arenisca permite pensar en un sistema de cubiertas semejante (Andreu et al. 2008: 99).

Las piezas de Santa Criz se situaron sobre la cornisa de tipo dórico del pórtico meridional de la plaza, que presenta la cara superior horizontal de $0,77 \mathrm{~m}$ de profundidad. Sirvieron de borde exterior al tejado al disponerse en la parte externa de la cornisa, dejando una franja de apoyo al interior de al menos $0,15 \mathrm{~m}$ para la colocación de la estructura horizontal del tejado. La cara biselada determinó la inclinación de la cubierta a dos aguas y sobre ella corrieron los cabrios de madera, existiendo espacio suficiente para alojar en cada ranura un par de vigas. La explicación podría encontrarse en la necesidad de disponer de una estructura lo suficientemente robusta como para soportar un tejado de piedra, cuyo peso podría llegar a suponer prácticamente el doble que el de uno de terracota (fig. 12).

\subsection{La interpretación funcional del conjunto excavado. Modelo arquitectónico}

La construcción de espacios públicos en lugares elevados creó un problema urbanístico ante la necesidad de mantener una cota regular suficientemente extensa para dotar a la ciudad de una plaza porticada convertida en su centro religioso, político y administrativo. La experiencia del helenismo romano aportó el sistema de terrazas, que se difundió a partir de época tardorrepublicana por las ciudades de la costa tirrénica de Italia y Magna Grecia para la configuración en altura de los nuevos espacios públicos (Etxebarria 2008: 82-85).

El sistema de tabernae o criptopórticos, a modo de galerías abovedadas, se desarrolló como solución 
habitual, repitiéndose en la disposición de los espacios públicos a partir del siglo II a.C. y hasta época augustea según el modelo forum-basilica-templum (Ward-Perkins 1970, Gros 1990).

En Santa Criz, la pared trasera del criptopórtico destinado a sostener el pórtico meridional del foro quedó limitada por un almacén de unos $500 \mathrm{~m}^{2}$ de superficie destinado al acopio de mercancías de distinta procedencia. De esta manera el diseño del espacio público de la civitas dejó fuera del foro la actividad comercial. La difusión, a partir de época tardorrepublicana, de un edificio de tipología reconocible y específico para la venta de productos alimentarios (De Ruyt 1973) acabaría sacando del foro a las tabernae, que habían ocupado hasta entonces, al menos, uno de los lados de la plaza.

La disposición del almacén siguió el modelo de las alineaciones de habitaciones regulares organizadas en hileras con una sola fachada -tabernae tabulatae-, cuyo antecedente se encuentra en la construcción de las grandes terrazas de los santuarios republicanos del Lacio (Mar 2005: 131); aunque su función no puede vincularse con negocios abiertos a una vía comercial sino con un establecimiento cerrado y con acceso controlado.

La riqueza agrícola del territorio administrado por la ciudad consiente un papel destacado en la recepción de productos alimentarios, principalmente cereal, que se guardaron en el almacén junto a otros productos importados, como evidencian los envases de vino tarraconense y salazones béticas hallados en su excavación.

Desde época tardorrepublicana conocemos horrea en el valle del Ebro para el acopio del grano, que reflejan el potencial económico agrícola de la zona. Emplazado en el centro del espacio urbano de Contrebia Belaisca (Botorrita, Zaragoza), un edificio de adobe sirvió como almacén. Con una superficie construida de $225 \mathrm{~m}^{2}$, presenta cinco naves alargadas abiertas a un pórtico (Medrano et al. 1991). A partir de época imperial, Caesar Augusta canalizaría, a través de su puerto, la salida de cereal de las ricas tierras de este valle y otros productos manufacturados hacia las áreas portuarias de Dertosa y Tarraco (Erice 2011: 152). Aunque desconocida la ubicación concreta de los horrea caesaraugustanos, las menciones al genius tutelae horreorum (CIL II 2991) y a un horrearius (Beltrán Lloris 1982: 56) en sendas inscripciones halladas en el casco urbano testimonian su existencia. De igual modo, la investigación ha querido ver estructuras horrearias próximas en Los Bañales de Uncastillo y en Campo Real/Fillera (Andreu 2011: 77-78), así como en la vecina villa de Liédena, ya en el territorio de los Iluberitani plinianos, aunque no lejos de Santa Criz de Eslava (Zuza 2013).

La estructura arquitectónica del edificio adosado al criptopórtico del foro de Santa Criz, con amplias naves alargadas, se asemeja a otros almacenes documentados en áreas portuarias de Roma y las provincias. Las formas reconocidas de los edificios destinados a almacenes son muy variadas, aunque la tipología más repetida presenta un cierto número de naves alineadas en fila o en torno a un patio central. En Roma proliferaron junto a los muelles fluviales, principalmente en el Emporium del Testaccio al pie de la colina Aventina (Sebastiani y Serlorenzi 2011), en Ostia y en Portus. Grandes puertos como Aquileia, Leptis Magna o Patara dispusieron también de almacenes donde agrupar las mercancías antes de su distribución. Los edificios destinados a tal fin presentaban naves estrechas y alargadas que, en ocasiones, se abrían a áreas porticadas (Rickman 1971: 132-138).

Construcciones similares se localizaron en el interior de las ciudades desde época tardorrepublicana. En ocasiones, se construyeron cerca de las puertas de la ciudad y, por tanto, bien comunicadas con las principales vías urbanas, como en la colonia latina de Cosa (Brown 1979) o en el municipium de Volsinii Novi (Gros 1981: 54-57), tal vez destinados a la conservación de alimentos para su venta en mercados locales.

En las inmediaciones de los fora se situaron algunos almacenes. Tal es el caso de los horrea Agrippiana en Roma, ubicados desde época augustea en el límite del foro republicano al sur de la basilica Iulia y destinados al depósito de bienes pero también a su venta (Astolfi 1996). De planta cuadrada y con una superficie ocupada de $3.600 \mathrm{~m}^{2}$, las habitaciones de planta alargada se organizaban en torno a un patio central (Rickman 1971: 91, fig. 20). Por su parte, en Tibur hacia mediados del siglo I a.C. se llevaron a cabo obras de ampliación en el foro, que incluyeron la construcción en el límite suroeste de la plaza de potentes subestructuras para ampliar el espacio público y que debieron funcionar como un gran almacén (Coarelli 1982: 86-90). La misma disposición se reconoce en otros núcleos urbanos del Lacio, donde en el municipium de Cora un edificio, de planta rectangular con varias naves cubiertas por bóvedas y con acceso a través de un corredor, sirvió de cimentación a la plaza del foro (v. Ribera 2011: 209-215).

En Hispania, estructuras de almacenamiento se han identificado en ciudades donde una gran parte de su actividad económica estuvo vinculada al comercio. Tarraco, Carthago Nova o Hispalis dispusieron de edificios destinados al almacén de mercancías importadas 


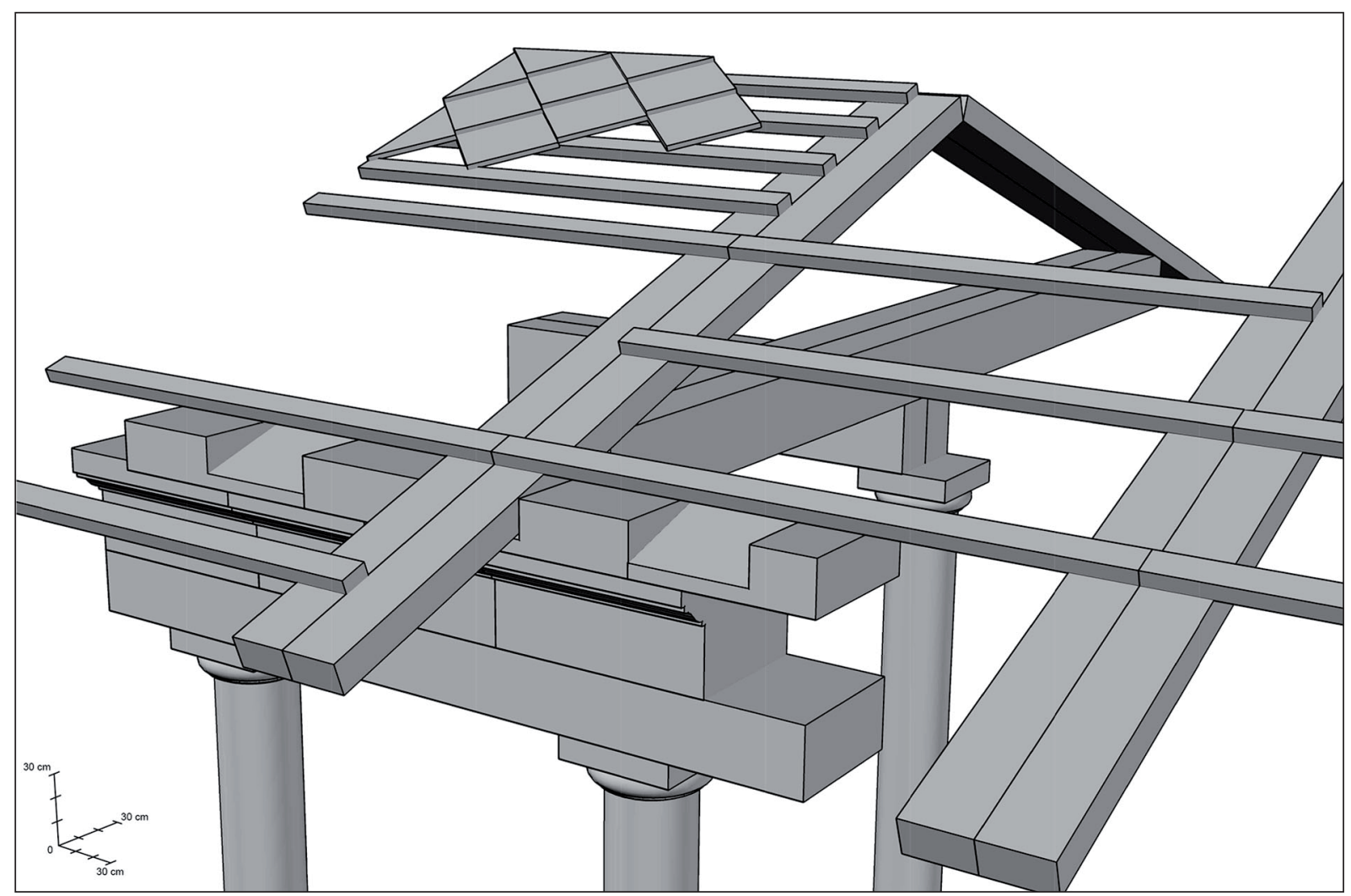

Figura 12. Propuesta interpretativa del sistema de cubierta del pórtico meridional del foro de Santa Criz (imagen: I. Hortelano).

y productos para exportación en las áreas portuarias. Este mismo carácter pudo tener el horreum construido a finales del siglo I o principios del II en Valentia, sobre el solar del antiguo almacén edificado al este de la plaza del foro en torno al 100 a.C. (Ribera 2011). Y quizás también las tabernae construidas en la primera mitad del siglo I a.C. en el costado suroriental de la terraza del foro de Baetulo, que ocuparon una superficie de $300 \mathrm{~m}^{2}$ (Guitart y Padrós 1990: 173).

Las diferencias formales entre los edificios identificados como almacén en el mundo romano son consecuencia de la inexistencia de un modelo estandarizado (Andreau 2007: 263), que impidió la difusión de una forma arquitectónica concreta por el resto de las provincias. El tipo arquitectónico de almacén conformado por una serie de largas y estrechas naves caracterizó a los edificios de almacenamiento construidos en ciudades de Asia Menor (Rickman 1971: 153). Mientras, el corredor de acceso que presentan algunos de ellos sirvió para proteger el grano de la entrada de agua desde la calle (Rickman 1971: 142).

El almacén de Santa Criz encuentra su precedente más cercano en la arquitectura de las naves del horreum de Contrebia Belaisca, mientras el modelo de habitaciones alargadas y corredor de acceso aparece en los grandes horrea de época adrianea de Myra y Patara en Licia (Rickman 1971: 137-140), de propiedad imperial (CIL III 6738 y 12129), o en el de Cuicul en Numidia (Papi y Martorella 2009: 178-182) construido en la primera mitad del siglo II d.C. (fig. 13).

La localización de tabernae en torno a los foros fue habitual en el mundo romano (v. Mar et al. 2015: 283287). Los establecimientos comerciales aparecen limitando uno de los costados de la plaza o al exterior de la misma, disposición más propia de época imperial cuando el forum desplazó la función comercial. Edificios comerciales adosados a los criptopórticos del foro se localizan en algunos conjuntos monumentales hispanos, como en Tarraco, donde aparecerán a una altura inferior a la plaza durante la reforma augustea del foro colonial (Mar et al. 2015: 258), en Valeria a partir de época tiberiana (Fuentes et al. 2007: 466-467) y en Los Bañales recorriendo el flanco sur de la plaza desde época augustea (Romero e.p.).

En el caso de Santa Criz el almacén se construyó fuera de la unidad arquitectónica del foro. Situado en la 


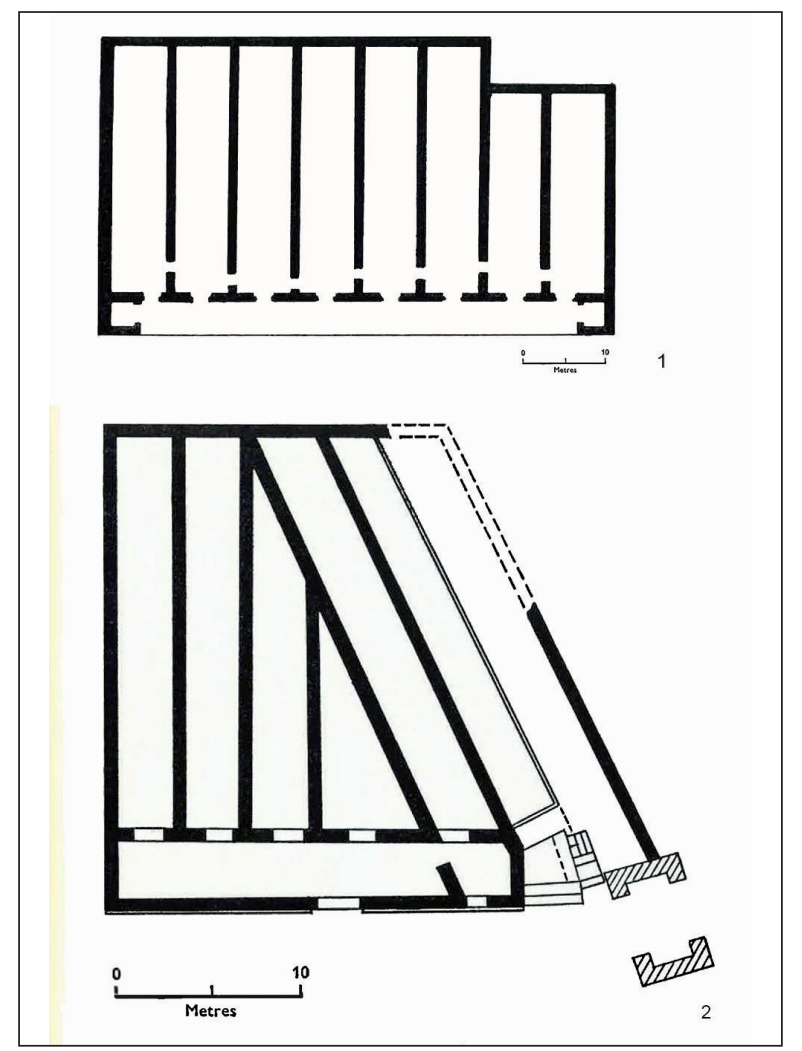

Figura 13. Planta de los almacenes de Myra (1) y Cuicul (2) con el mismo esquema arquitectónico del de Santa Criz de Eslava (imagen tomada de Rickman 1971: Figuras 31 y 32).

trasera del porticado de la plaza, que se elevaba sobre el criptopórtico, fue un edificio público relacionado con la actividad comercial de la ciudad pero alejado de la funcionalidad político-administrativa y religiosa del forum. Abierto a una calle E-O, que comunicaba con una de las puertas de la ciudad, la única vinculación con el centro cívico fue quizás la ubicación de los accesos a la plaza a través de sendas escaleras situada en el lado occidental y oriental del edificio. Esta disposición junto a la entrada de la ciudad facilitaría el transporte y el comercio de los productos alimentarios custodiados a corto y medio plazo en el almacén y destinados al aprovisionamiento de la ciudad.

\section{LA DECORACIÓN ARQUITECTÓNICA DEL FORO. ESTILO Y CRONOLOGÍA}

Durante los trabajos arqueológicos se encontraron caídos y amontonados en el interior del criptopórtico y en la nave más occidental del almacén numerosas basas, fustes, capiteles, cornisas y sillares, junto a algunos fragmentos de estatuaria, zócalos y coronamientos de pedestales de estatua, altares votivos y varias inscripciones. Aparecieron en la posición de caída en la que quedaron tras el colapso y derrumbe del pórtico meridional del foro y del edificio situado en el costado occidental de la plaza (fig. 14). La atribución de todos los fragmentos de decoración arquitectónica a edificios públicos queda confirmada por las proporciones, riqueza decorativa y buena ejecución. La mayoría de las piezas se conservan completas y pertenecen a distintos órdenes arquitectónicos, sobre todo corintio y dórico/toscano, al que se une un capitel de orden compuesto (tab. 1).

Un primer grupo de piezas lo constituyen elementos en orden corintio, que incluyen tanto capiteles de columna como de pilastras (Romero 2018: 206-207, Andreu et al. 2019a). La altura de todos ellos es idéntica, aproximadamente $70 \mathrm{~cm}$, y presentan igual desarrollo de kalathos y ábaco. Asociados al orden de columnas, hay fustes estriados y basas áticas. Asimismo, del orden de pilastras se conservan fustes estriados y basas pertenecientes a este orden arquitectónico. Por su posición de caída en el criptopórtico y uniformidad en cuanto a dimensiones y estilo, debieron de formar parte de la decoración arquitectónica de un edificio ubicado en la zona occidental del foro de Santa Criz de Eslava. Este edificio sería arrastrado total o parcialmente en el momento del colapso del ángulo suroccidental del foro. En cuanto a la cronología de este grupo, los capiteles son de los denominados corintios normales de finales de época republicana y comienzos del Imperio (Romero 2018: 206-207, Andreu et al. 2019a). Las piezas de columna y de pilastra son idénticas estilísticamente. Se caracterizan por la utilización de un acanto simétrico, con sombras de aspecto geométrico en la zona de unión de los lóbulos de hojitas lanceoladas. Los caulículos son rígidos, inclinados y con acanaladuras verticales. Ambas folias de acanto presentan casi idéntica altura, de aproximadamente $16 \mathrm{~cm}$. Las hojas de acanto se encuentran divididas en cinco lóbulos de hojitas que presentan un corte de hoja de época medioaugustea, idéntico al que poseen otros capiteles hispanos, como los de la basílica de Segobriga (Abascal et al. 2004: 250-253, Trunk 2008: 13-21). Su rasgo estilístico más significativo es la presencia de sendas rosetas en las enjutas, como las que se dan en los capiteles corintios del denominado estilo del Segundo Triunvirato (Heilmeyer 1970: 36-42, Pensabene 1973: 207-208, Roth-Congès 1983: 106, Mar et al. 2015: 313-315). Esta tipología con rosetas está presente en Roma entre los años 30-20 a.C., 


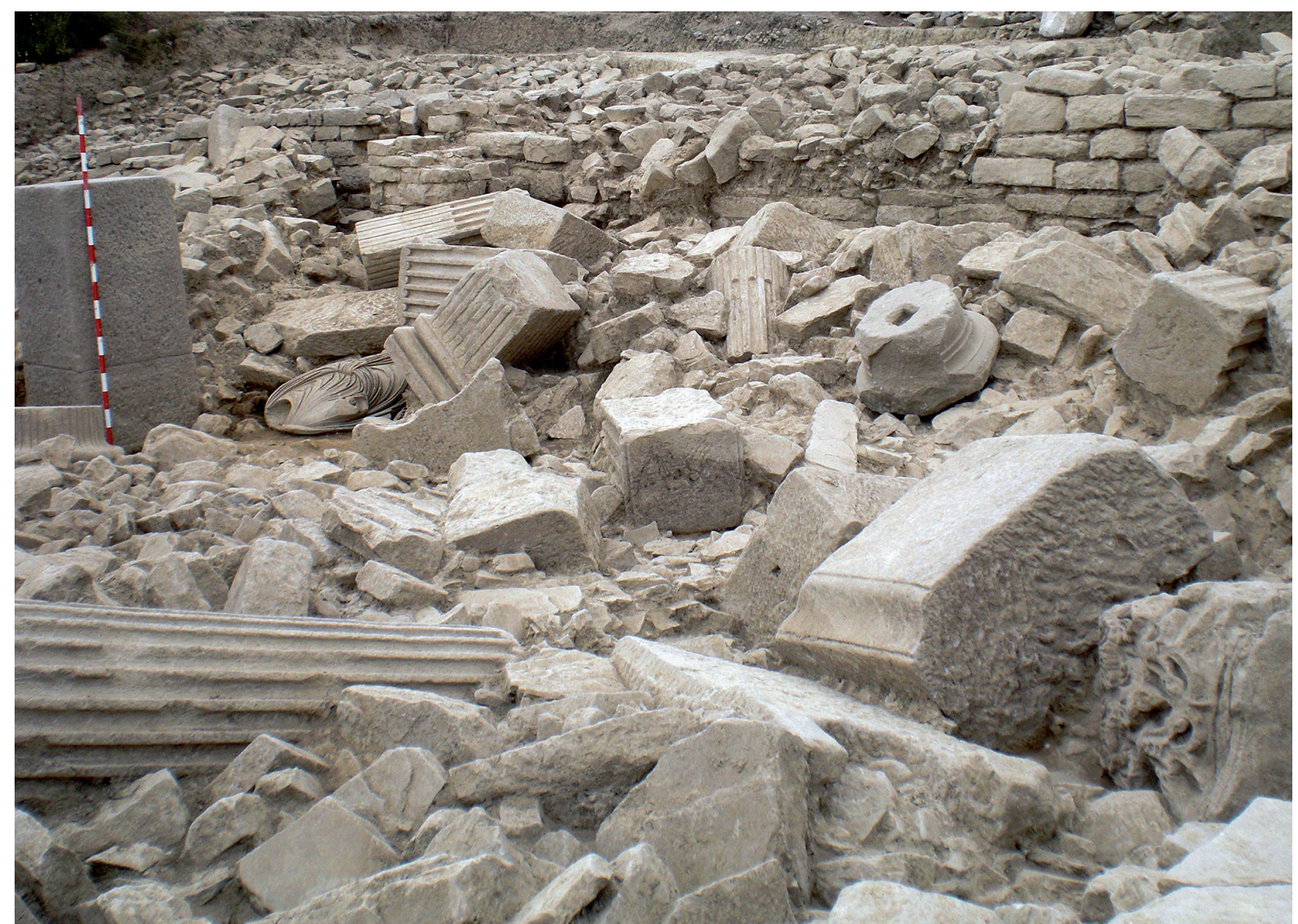

Figura 14. Nivel de derrumbe en el interior del criptopórtico con los restos de una estatua togada y elementos arquitectónicos de la decoración del foro (imagen: R. Mateo).

sobreviviendo en algunos casos hasta el cambio de era. Los ejemplares metropolitanos más cercanos son los del templo de Apolo Capitolino (Heilmeyer 1970: 37). En la Galia, aparecen a partir del 20 a.C. y se convierten casi en exclusivos en la parte occidental del Imperio a partir del 10 a.C., donde sobreviven hasta bien entrado el s. I d.C. (Roth-Congès 1983: 103-134). Este tipo de capiteles son muy frecuentes en Hispania (Gutiérrez Behemerid 1992: 70-72) y en especial en la Tarraconense. Dentro de su ámbito geográfico más cercano, en el conventus Caesaraugustanus, se dan en la propia capital conventual Caesar Augusta (Beltrán Lloris y Paz Peralta 2014: 105), en Osca (Asensio y Justes 2014: 29-42) o en Cara (Gutiérrez Behemerid 1992: 79, $\mathrm{n}^{\mathrm{o}}$ 206-209). Entre las piezas hispanas con rosetas en las enjutas, destacan los citados de la basílica segobrigense, los del teatro de Tarraco o los del templo de Barcino (Domingo et al. 2011: 852-856). En los ejemplares de columna, es significativo el delicado trabajo en tres lados y ausencia de trabajo en la cara posterior, donde la arenisca apenas está desbastada y sin presencia de alisado. La explicación es que el capitel no debía verse en esta zona o su visión debió de ser parcial. Idéntico tratamiento presenta un capitel corintio del pórtico del foro provincial de Tarraco, aunque datado en época adrianea (Mar et al. 2015: 148-149).

Los elementos arquitectónicos se encontraban estucados en tonos ocre. Los restos de estuco se conservan en los capiteles de columna, en los de pilastra y en uno de los fustes de pilastra. En los capiteles de pilastra, el estuco se ha preservado en casi toda la superficie, a excepción de la parte superior derecha de uno de ellos y la parte inferior izquierda del otro ejemplar, al haberse hallado fragmentados. El empleo de estuco en decoración arquitectónica es bastante habitual y se encuentra con bastante profusión en Hispania, sobre todo cuando las piezas están realizadas en piedra arenisca. Buen ejemplo de ello son los capiteles del denominado templo de Diana de Augusta Emerita (De la Barrera 1984: 33-34, n 20, De la Barrera 2000: 23-24) 
Tabla 1. Inventario y ordenación de las piezas de decoración arquitectónica procedentes de las excavaciones realizadas en Santa

\begin{tabular}{|c|c|c|c|c|c|}
\hline \multirow{2}{*}{$\begin{array}{l}\text { Primer } \\
\text { grupo }\end{array}$} & \multirow[t]{2}{*}{ orden corintio } & de columna & $\begin{array}{l}\text { capiteles } \\
\text { fustes estriados } \\
\text { basas áticas sin plinto } \\
\text { cornisa con modillones }\end{array}$ & $\begin{array}{l}3(\mathrm{ESL} 2 / 3,4 \text { y } 10) \\
11(\mathrm{ESL} 1 / 18 \text { a } 23 \text { y } 25 \text { a } 29) \\
4 \text { (ESL } 1 / 29-32) \\
1(\text { ESL } 1 / 126)\end{array}$ & $\begin{array}{l}10 \text { a.C } / 10 \\
\text { d.C }\end{array}$ \\
\hline & & de pilastra & $\begin{array}{l}\text { capiteles } \\
\text { fustes estriados } \\
\text { basas áticas sin plinto }\end{array}$ & $\begin{array}{l}4(\mathrm{ESL} 1 / 85 \text { y } 91-92) \\
5(\mathrm{ESL} 1 / 24,1 / 56,1 / 59,1 / 60 \text { y } 1 / 67) \\
3(\mathrm{ESL} 1 / 62,1 / 64 \text { y } \mathrm{ESL} 4 / 3)\end{array}$ & $\begin{array}{l}10 \text { a.C/10 } \\
\text { d.c }\end{array}$ \\
\hline $\begin{array}{l}\text { Segundo } \\
\text { grupo }\end{array}$ & orden corintio & de pilastra & $\begin{array}{l}\text { capiteles } 2 \text { lados } \\
\text { capiteles } 3 \text { lados } \\
\text { fustes estriados } 2 \text { lados } \\
\text { fustes estriados } 3 \text { lados } \\
\text { basa ática con y sin plinto } \\
\end{array}$ & $\begin{array}{l}2(\operatorname{ESL} 2 / 6 \text { y } 9) \\
2(\operatorname{ESL} 2 / 2 \text { y } 5) \\
3(\operatorname{ESL} 1 / 55,1 / 65 \text { y } 1 / 66) \\
5(\operatorname{ESL} 1 / 53,1 / 57,1 / 58,1 / 61 \text { y } 1 / 63) \\
3(\operatorname{ESL} 1 / 53,1 / 61 \text { y } 1 / 63) \\
\end{array}$ & $\begin{array}{l}2^{\mathrm{a}} \text { mitad I } \\
\text { d.C. }\end{array}$ \\
\hline $\begin{array}{l}\text { Tercer } \\
\text { grupo } \\
\end{array}$ & orden corintio & de columna & $\begin{array}{l}\text { capiteles } \\
\text { fustes estriados }\end{array}$ & $\begin{array}{l}1 \text { (ELS 1/92) } \\
4(\text { ESL 1/128-131) } \\
\end{array}$ & $\begin{array}{c}1^{1 a} \text { mitad I } \\
\text { d.C. }\end{array}$ \\
\hline $\begin{array}{l}\text { Cuarto } \\
\text { grupo }\end{array}$ & orden toscano & de columna & $\begin{array}{l}\text { capiteles } \\
\text { fustes lisos } \\
\text { basa toscana } \\
\text { basa toscana de pilastra } \\
\text { basa ática } \\
\text { basa ática de pilastra } \\
\text { cornisa }\end{array}$ & $\begin{array}{l}7(\mathrm{ESL} 1 / 15-17 \text { y } \mathrm{ESL} 2 / 11-14) \\
26(\mathrm{ESL} 3 / 13,17,19,22,25-33,35,60, \mathrm{ESL} 3 / 0-01 \\
\text { y } 02, \mathrm{ESL} 3 / 2-12, \mathrm{ESL} 3 / 5-02, \mathrm{ESL} 3 / 6-08,14,15,21 \\
\text { y } 29, \mathrm{ESL} 3 / 7-05 \text { y } 06 \text { y } 10) \\
1(\mathrm{ESL} 1 / 40) \\
1(\mathrm{ESL} 1 / 52) \\
4(\mathrm{ESL} 1 / 13-14 \text { y ESL } 4 / 1-2) \\
2(\mathrm{ESL} 1 / 54 \text { y ESL } 5 / 1) \\
4(\mathrm{ESL} 1 / 34,1 / 48-1 / 50)\end{array}$ & $\begin{array}{l}\text { Época } \\
\text { Augustea }\end{array}$ \\
\hline
\end{tabular}

o los del templo de Barcino (Domingo et al. 2011: 851854). El color ocre se empleó para simular el color oro -ya que el pan de oro era costosísimo- y estaba reservado para unas edificaciones muy concretas. Habitualmente, se utilizó para los capiteles de edificios religiosos, como se ha constatado en Hispania en el templo de culto imperial del forum novum de Corduba (Portillo 2016: 28-33) o en algunos edificios forenses, como es el caso de la basílica del cercano foro de Los Bañales de Uncastillo (Romero 2017: 126-127). En los capiteles de columna, la presencia de estuco es mucho más escasa, conservándose sobre todo en las zonas de las hojas de acanto. La idéntica altura que las piezas anteriores, unida al citado tratamiento de estucado en tonos amarillentos, parece apuntar a que los cinco capiteles y los fustes de columna y basas asociables a ellos pertenecieron a un mismo edificio, datado en época augustea (fig. 15).

El segundo grupo lo constituye un orden arquitectónico corintio de pilastra trabajados por dos y tres lados. Se han conservado dos capiteles del orden corintio de pilastra con labra por dos lados y otros dos trabajados por tres caras. Asociados al orden de pilastra con labra por dos lados existe una serie de fustes estriados, con esquema idéntico de cuatro acanaladuras y cinco listeles, de $43 \mathrm{~cm}$ de anchura.

Al orden trabajado por tres lados puede vincularse una serie de fustes, que miden entre 45 y $53 \mathrm{~cm}$, algunos de ellos con basa ática sin plinto en la misma pieza. Su desarrollo es también igual, con cuatro acanaladuras y cinco listeles. Los capiteles presentan características estilísticas similares, aunque con algunas diferencias. Además, poseen dimensiones diversas que oscilan entre alturas de $49 \mathrm{~cm}$ y $69 \mathrm{~cm}$. Las hojas de acanto son bastante extendidas, cortas y muy pegadas al cuerpo del capitel excepto el borde superior de cada una de ellas. Estas hojas poseen lóbulos de cuatro y cinco hojitas lanceoladas que acaban con un perfil redondeado y con zonas de sombra en forma triangular. Las volutas y las hélices, presentan forma de cinta y están recorridas por una incisión. Los caulículos son casi rectos, aunque con una ligera inclinación hacia los lados, a diferencia de los ejemplares del estilo del Segundo Triunvirato, cuya inclinación es más acusada. Presentan diferencias en los calículos en función del ejemplar, con estrías verticales -la gran mayoría de ellas- y algunas oblicuas. La tendencia vertical de los caulículos, empieza a darse a partir de época julioclaudia, aunque en algunas ciudades se mantiene la inclinación hacia los lados del periodo augusteo. En la Tarraconense se conservan bastantes ejemplos, entre los que sobresalen los casos de las termas públicas de Tarraco o algunas piezas de Barcino (Domingo 2005: 51-56). Presentan una altura de las coronas de aproximadamente la mitad de altura del capitel, aspecto este observado desde 


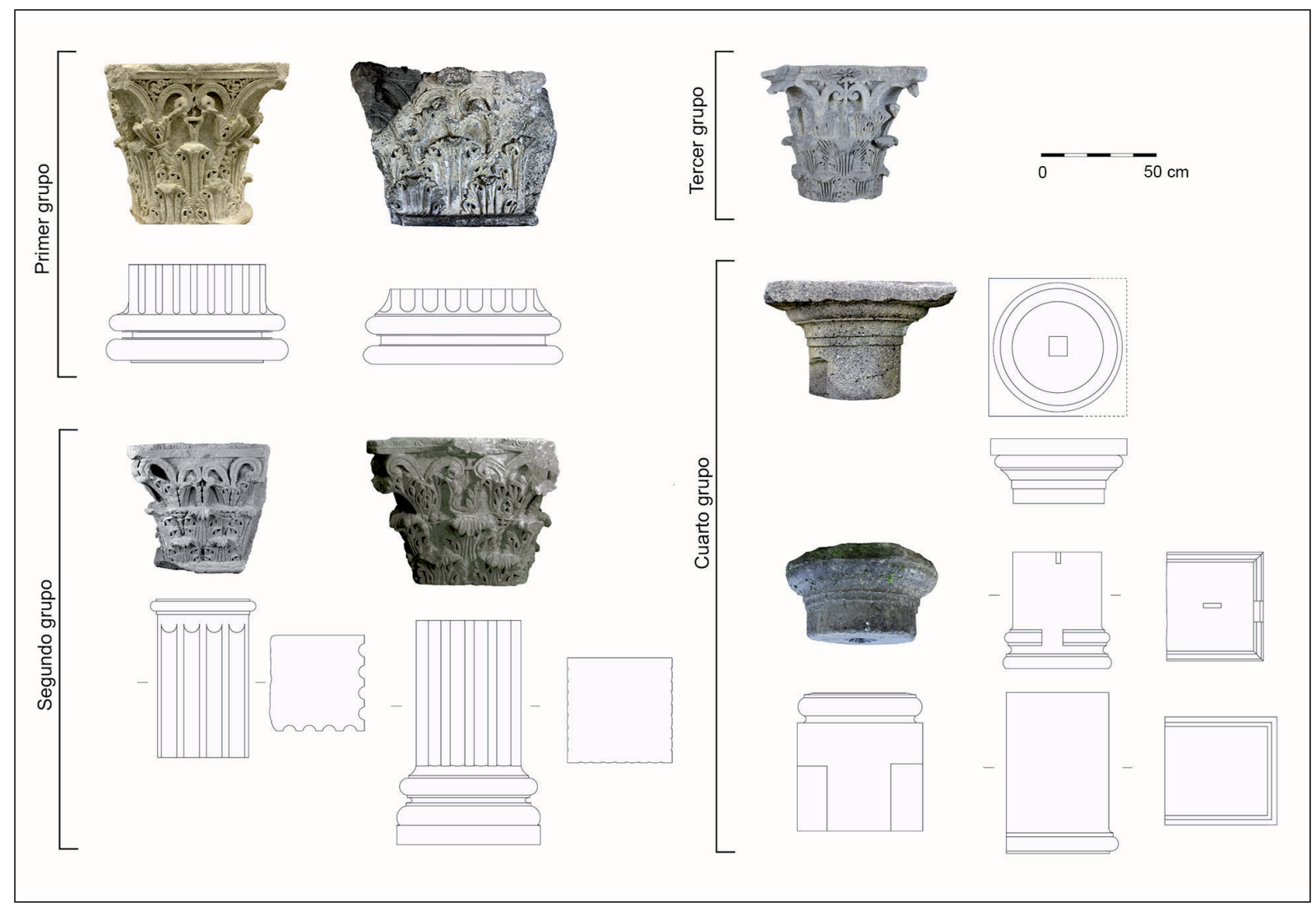

Figura 15. Conjunto de elementos arquitectónicos y dimensiones hallados en la excavación de Santa Criz de Eslava (fotografías: L. Romero, dibujos: I. Diéguez, montaje: R. Cebrián).

época julioclaudia hasta finales del s. I d.C. (Gutiérrez Behemerid: 1992, 132). Se advierte sobrecarga ornamental de las piezas que lleva a decorar casi toda la superficie disponible, a excepción de una pequeña zona entre el cáliz de la flor del ábaco y los calículos y cálices. Sin embargo, no llega al barroquismo de ciertos ejemplares datados en época flavia (Gutiérrez Behemerid 2004: 281 y 286). Este ciclo de capiteles se caracteriza por la enorme tosquedad en la ejecución, la presencia de asimetrías e importantes errores de cálculo a la hora de ejecutar el modelo en el que se inspiraron. Este aspecto parece indicar que fueron elaborados por un taller claramente provincial entre finales de época julioclaudia y flavia.

La ausencia de excavaciones en la plataforma superior al criptopórtico, donde previsiblemente se situó la plaza del foro rodeada de pórticos y de los edificios religiosos y administrativos de la ciudad, impide conocer con certeza la ubicación concreta de las piezas de decoración arquitectónica de estos dos grupos. La posición de caída y, sobre todo, la combinación de un orden corintio idéntico, de columnas exentas y pilastras ambas estucadas, de la serie asignada al primer grupo permite plantear la hipótesis de su adscripción a la basílica jurídica, edificada en época augustea en el costado occidental de la plaza forense. Los elementos exentos formarían parte de la peristasis columnada y las piezas de pilastra pudieron decorar la pared del fondo de la basílica. Para el segundo grupo es posible sugerir una ubicación en la fachada de la basílica, donde no existiría un pórtico hacia la plaza sino un sistema de puertas en arco decoradas por pilastras.

Un tercer grupo lo constituye un orden corintio de columna de fuste mucho más pequeño que el atestiguado en el primer conjunto de elementos arquitectónicos, para el que de momento no contamos con una propuesta de situación. Está compuesto por un capitel de columna, con un diámetro de sumoscapo de 34 $\mathrm{cm}$ y fustes estriados vinculables conservados en el derrumbe ubicado en la nave más occidental del almacén. El capitel de columna se encuentra trabajado por todos sus lados -a diferencia de los del estilo del Segundo 
Triunvirato- y se ha preservado en muy buen estado de conservación. Ha sido limpiado y restaurado durante el año 2018. Su característica técnica más llamativa es la tendencia vertical del caulículo a diferencia de los otros capiteles corintios que presentan inclinación hacia los lados. Este aspecto se da desde época julioclaudia, aunque hay piezas que mantienen la tendencia hacia los lados del mismo. En las hojas de acanto, las hojitas siguen la tradición de los capiteles del estilo del Segundo Triunvirato, sin presentar formas más redondeadas, típicas de cronología julioclaudia, como ocurre en los capiteles del segundo grupo. Destaca la gran profundidad de los surcos de las nervaduras centrales de los acantos, aspecto también propio de ejemplares vinculables a época julioclaudia. Por tanto, el capitel puede datarse en época de Tiberio-Claudio, en con base a en la continuación de ciertos rasgos estilísticos de los capiteles del estilo del Segundo Triunvirato y en la presencia de elementos propios de época julioclaudia, como la tendencia más vertical del caulículo o los profundos surcos presentes en las nervaduras centrales de las hojas de acanto. También hacia esta cronología apunta la proporción de las folias de acanto, aún muy inferior a la mitad de la altura del capitel, y solo superada a partir de finales del s. I d.C.

El cuarto grupo lo compone una serie de elementos en orden dórico/toscano con abundantes piezas. Los capiteles toscanos forman un conjunto de siete ejemplares en el que se pueden distinguir dos grupos teniendo en cuenta su diámetro. Todos ellos se caracterizan por la misma secuencia de elementos decorativos. Las medidas del ábaco oscilan entre 60 y $70 \mathrm{~cm}$ de lado y un espesor de $10 \mathrm{~cm}$. El diámetro de sumoscapo es de 40 y $49 \mathrm{~cm}$. Los fustes de estos capiteles son lisos, habiéndose documentado una serie de veintiséis con diámetros que oscilan entre los 40 y los $55 \mathrm{~cm}$. Al mismo grupo se vincula una basa toscana con diámetro en el imoscapo de $46 \mathrm{~cm}$ y quizás cuatro basas áticas.

Por la enorme cantidad de piezas y la existencia de abundantes fustes lisos, parece lógico plantear que ambas hileras del pórtico meridional del foro emplearon este tipo de columna. Más problemático es el tipo de orden utilizado en la primera galería del pórtico. Por los elementos conservados es posible plantear que se realizó en orden toscano provincial a partir del hallazgo de cuatro basas áticas -de 46-47 cm de diámetro- con fustes lisos, en la excavación del criptopórtico. Se asocian al orden toscano provincial al no presentar plinto, un toro inferior más grande que el superior y escocias de tamaño medio, con perfiles de sección cóncava semicircular entre dos listeles. La singularidad del orden toscano en la zona vascona era ya conocida por otro capitel de desarrollo muy alejado de los cánones, localizado en el criptopórtico del foro de Los Bañales de Uncastillo (Romero 2017: 117-118, n 1). El orden toscano provincial con basas áticas sin plinto nos proporciona una cronología en la segunda mitad del s. I a.C e inicios del Principado, a partir de los ejemplos en otras ciudades hispanas, como en Carthago Nova (Noguera y Madrid 2013: 237) o en la basílica del foro de Los Bañales en un programa datado en época augustea temprana (Romero 2017: 127-128). Sin embargo, también es plausible plantear que la galería exterior se realizó en orden dórico y que las basas áticas corresponden a otro edificio sin identificar del foro de Santa Criz de Eslava. A este mismo grupo se adscribe una basa de pilastra toscana y, al menos, otras dos basas de pilastras áticas, cuya posición original queda incierta.

El empleo del orden toscano en los pórticos es muy habitual desde épocas tempranas en la península itálica, como en el foro de Cosa (Brown et al. 1993: 122, Etxebarria 2008: 138) o ya en época imperial en los de Rusellae (Dell'Acqua 2012: 21-34), Sassina (Ortalli 1995: 278-279) o Scolacium (Donzelli 1991: 489). Los capiteles no siguen ninguno de los tipos propuestos por P. Broise (1969: 17-20), aunque su desarrollo es parecido al modelo AC, si bien en el caso de los capiteles de Santa Criz el sumoscapo tiene un tratamiento diferente. Tienen por tanto una estructura de ábaco + equino en arco de círculo + caveto + collarino liso. Los ejemplares del tipo AC se atestiguan frecuentemente en la Galia, como por ejemplo en el gran pórtico de la Villasse de Vaison-la-Romaine, la casa des Antes y la casa d'Atys de Glanum (Broise 1969: 20). En Hispania, hay ejemplares del tipo AC en $T a-$ rraco (Gimeno 1989: 117-118) o Saguntum (Chiner 1990: 77-78). Idéntico desarrollo, con sumoscapo similar al de los capiteles de Santa Criz de Eslava, se da en una pieza en orden toscano de Barcino que ha sido interpretada como una basa (Gimeno 1991: 62-63, $\mathrm{n}^{\circ}$ 9; Escrivà 2005: 17-18, n ${ }^{\circ} 7$ ). Las piezas también son parecidas al tipo BC de P. Broise (1969: 17-20), aunque en esta tipología el equino no es de arco de círculo.

El empleo del orden dórico en los pórticos forenses es también muy frecuente en la arquitectura romana desde fechas muy tempranas, con ejemplos en los foros de Minturnae, Praeneste o Pompeya (Etxebarria 2008: 136-138). En época imperial se continuó usando con bastante frecuencia en los foros itálicos, caso de Luni (Rossignani 1995: 464) o de Assisi (Sisani 2006: 100-101). Su uso en los fora hispanos es también muy 
habitual y se encuentra desde época tardorrepublicana en los pórticos del foro de Emporiae (Gimeno 1989: 107-112) e inicios de época augustea en Segobriga (Abascal et al. 2007: 387).

La serie de piezas de cornisas que puede asociarse al pórtico meridional del foro de Santa Criz presenta un estilo arcaico, en ellas se ha tallado una faja seguida de una cyma recta entre dos listeles en la parte alta de un paralelepípedo. Una de ellas corresponde a una pieza angular, que pudo situarse en la esquina occidental del pórtico.

\section{LA AMORTIZACIÓN DEL ALMACÉN PÚBLICO Y EL REFUERZO DEL CRIPTOPÓRTICO}

La interpretación del conjunto excavado en Santa Criz determinó dos fases de reformas consecutivas entre la segunda mitad del siglo I d.C. (fase II) y primera mitad del siglo II d.C. (fase III). Los lienzos de la fase original (fase I) se distinguen por estar construidos en opus vittatum, de hiladas horizontales y bien aparejadas, mientras los de la fase II y III presentan tongadas de diferentes alturas, en ocasiones inclinadas, y la inserción de lajas en casi todas las filas. La fase II quedó individualizada por la elevación de nuevos pilares de refuerzo en el muro sur del criptopórtico y en los muros de las naves longitudinales situadas en los extremos del almacén. La fase III, por la construcción de entrepaños entre aquellos pilares y el apuntalamiento del lienzo de la muralla republicana, y el cierre meridional del criptopórtico resuelto por contrafuertes (Armendáriz et al. 2016: 250-251).

Esta explicación partía de la transformación del almacén en una plaza rodeada de un pórtico en forma de $\mathrm{U}$ abierta hacia el sur y el consiguiente uso del criptopórtico, que conllevó el desmontaje de los muros de las naves y la sobreelevación de la cota de circulación tanto en el almacén como en el interior del criptopórtico (fase II). En la fase III se produciría la amortización de este pórtico, que no impediría la continuidad del uso del espacio como plaza limitada ahora por un deambulacro perimetral.

En realidad, esta lectura plantea serias dudas difíciles de aceptar desde el punto de vista constructivo, relativas, sobre todo, a la situación en la que quedaría el pórtico meridional del foro. La propuesta es incompatible con la permanencia de este pórtico al desaparecer el elemento estructural GEM 4, que permitiría el apoyo del forjado.
A partir de aquí la búsqueda de una explicación más verosímil nos lleva a plantear la siguiente hipótesis. La reestructuración del espacio supuso la demolición del almacén público. Su desaparición en el marco de una reforma es segura por la ausencia de derrumbes, el desmontaje de los muros hasta alcanzar una misma cota y la existencia de un vertido de nivelación (UE 786=787), cuya finalidad fue sobreelevar la cota de circulación por encima de estos muros. Esta sobreelevación también afectó al interior del criptopórtico (UE 65), ahora transitable con la apertura en el muro meridional de dos puertas en los extremos este y oeste.

La demolición del almacén generó un problema estructural grave en el criptopórtico al perder la construcción que le servía de apoyo. Así es posible imaginar que el muro meridional comenzó a vencerse hacia el exterior, obligando a acometer obras de refuerzo. Los trabajos de saneado de este muro debieron obligar a su desmontaje hasta el nivel donde se encontrara sin afecciones, lo que queda evidenciado en las diferentes alturas mantenidas a lo largo de su traza. A partir de aquí se reconstruyó con los mismos sillarejos empleando una fábrica similar pero de peor factura, en la que se introdujeron elementos verticales de refuerzo semejantes a los originales. Estos nuevos pilares se cimentaron sobre el degollado muro original GEM 4. Algunos de los sillares que conformaron estos pilares presentan entalladuras para el encaje de las vigas del forjado, que ya hemos descrito. Ello demostraría que aun cuando parte de este forjado pudo desmantelarse durante las obras, fue repuesto simultáneamente (fig. 16).

También se instalaron nuevos pilares sobre los muros de las naves situadas en el extremo oriental y occidental del almacén, convertidas ahora en los pasillos de acceso al interior del criptopórtico. Los cuatro sillares conservados en uno de los machones del lado oeste presentan marcas epigráficas en la parte superior e inferior de la misma cara, que sirvieron para indicar a los operarios la colocación exacta de las piezas. La coincidencia entre el numeral tallado en la parte superior del sillar y el de la parte inferior del siguiente sugiere esta idea (Andreu et al. 2019b: 32-35, n 4). A pesar de la ejecución de los trabajos de refuerzo, los problemas estructurales persistieron. La solución adoptada pasó por la construcción de contrafuertes en el interior del criptopórtico, que aseguraron su muro meridional, uno de los pilares internos y la muralla.

El foro acabaría derrumbándose a lo largo del siglo III d.C. debido a un fallo estructural perceptible en el costado noroccidental del criptopórtico, donde se observa que el lienzo exterior de la muralla se encuentra 


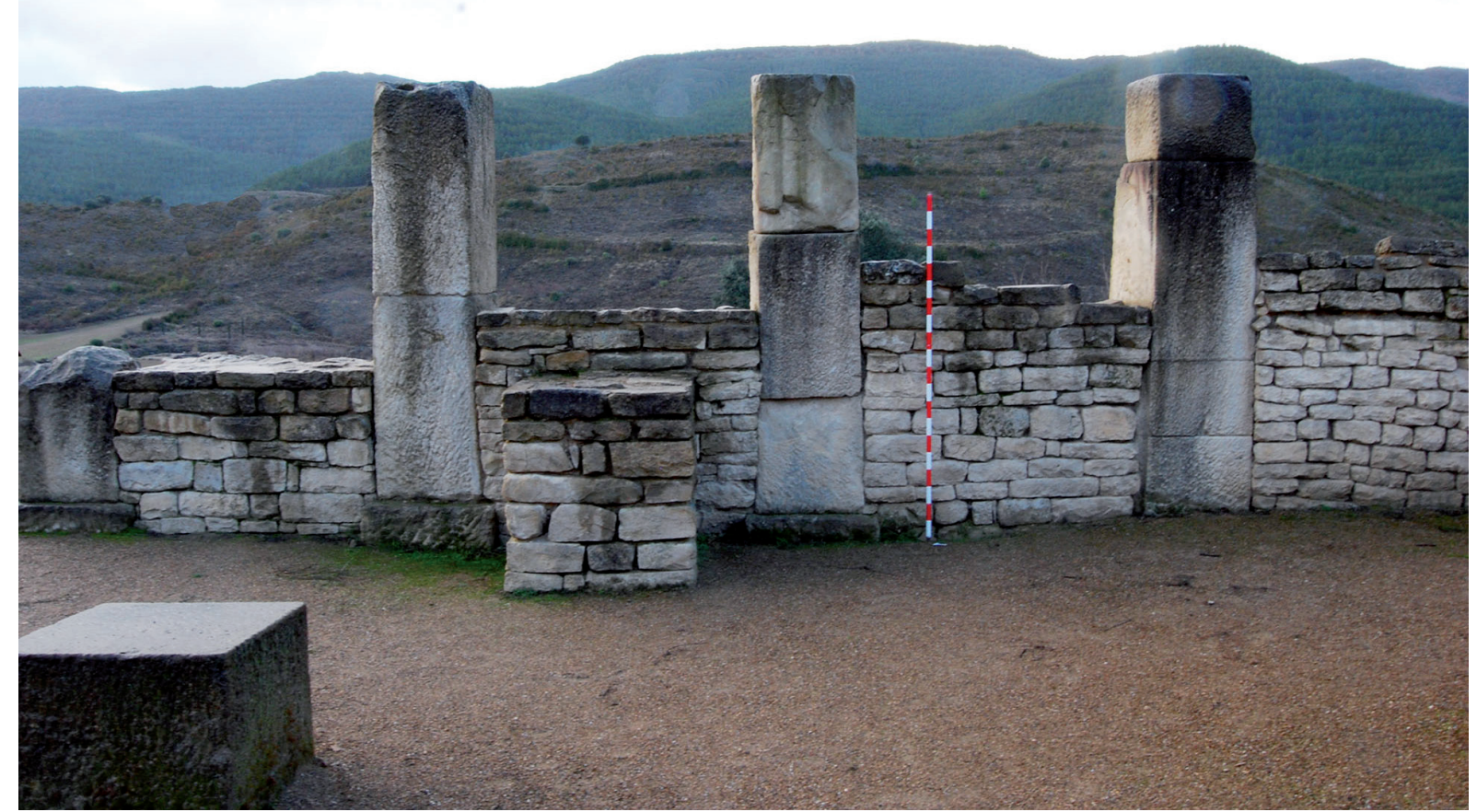

Figura 16. Estado en el que quedó el muro GEM 4 tras la reforma, visto desde el interior del criptopórtico (imagen: R. Cebrián).

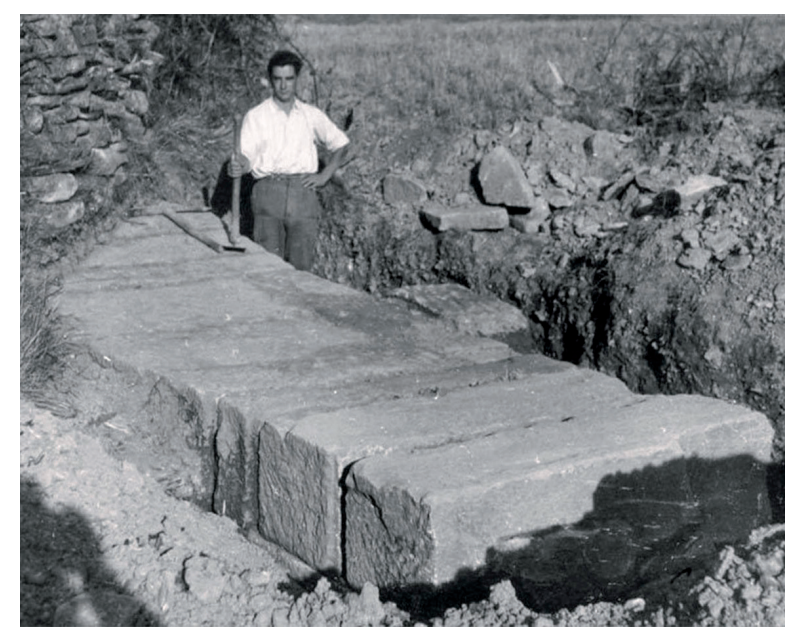

Figura 17. Fotografía del basamento de sillares hallado por B. Taracena y L. Vázquez de Parga en 1944 (imagen: Archivo de la Institución Príncipe de Viana, Gobierno de Navarra).

desplomado hacia el interior de la subestructura. Posiblemente cedió por empujes del terreno, afectando al edificio situado en el lado occidental de la plaza y al pórtico meridional, que provocarían su destrucción.

\section{A MODO DE RECAPITULACIÓN. PROPUESTA INTERPRETATIVA DEL CENTRO CÍVICO DE SANTA CRIZ}

Los hallazgos arqueológicos en Santa Criz corresponden a una pequeña parte de su centro monumental. El proyecto de investigación actualmente en marcha prevé la excavación sistemática del conjunto forense en los próximos años, que determinará su arquitectura y fases constructivas, por lo que plantear una hipótesis reconstructiva parece de momento aventurado aun cuando se puede esbozar una propuesta interpretativa inicial.

El descubrimiento en 1944 de un basamento con sillares dispuestos a tizón al norte del espacio excavado confirma la existencia de edificios públicos situados en torno a la plaza del foro (fig. 17). Aunque desconocemos el lugar exacto donde se encontró, a unos $22 \mathrm{~m}$ del límite septentrional del criptopórtico y en su franja oriental se localiza semienterrado un sillar de 1,54 m de longitud, que podría formar parte de este podium. Esta obra de sillería podría identificarse con el basamento de un templo que presidiría la plaza por su lado oriental.

En el límite sur del foro se sitúa el criptopórtico destinado a sostener uno de los pórticos de la plaza. 


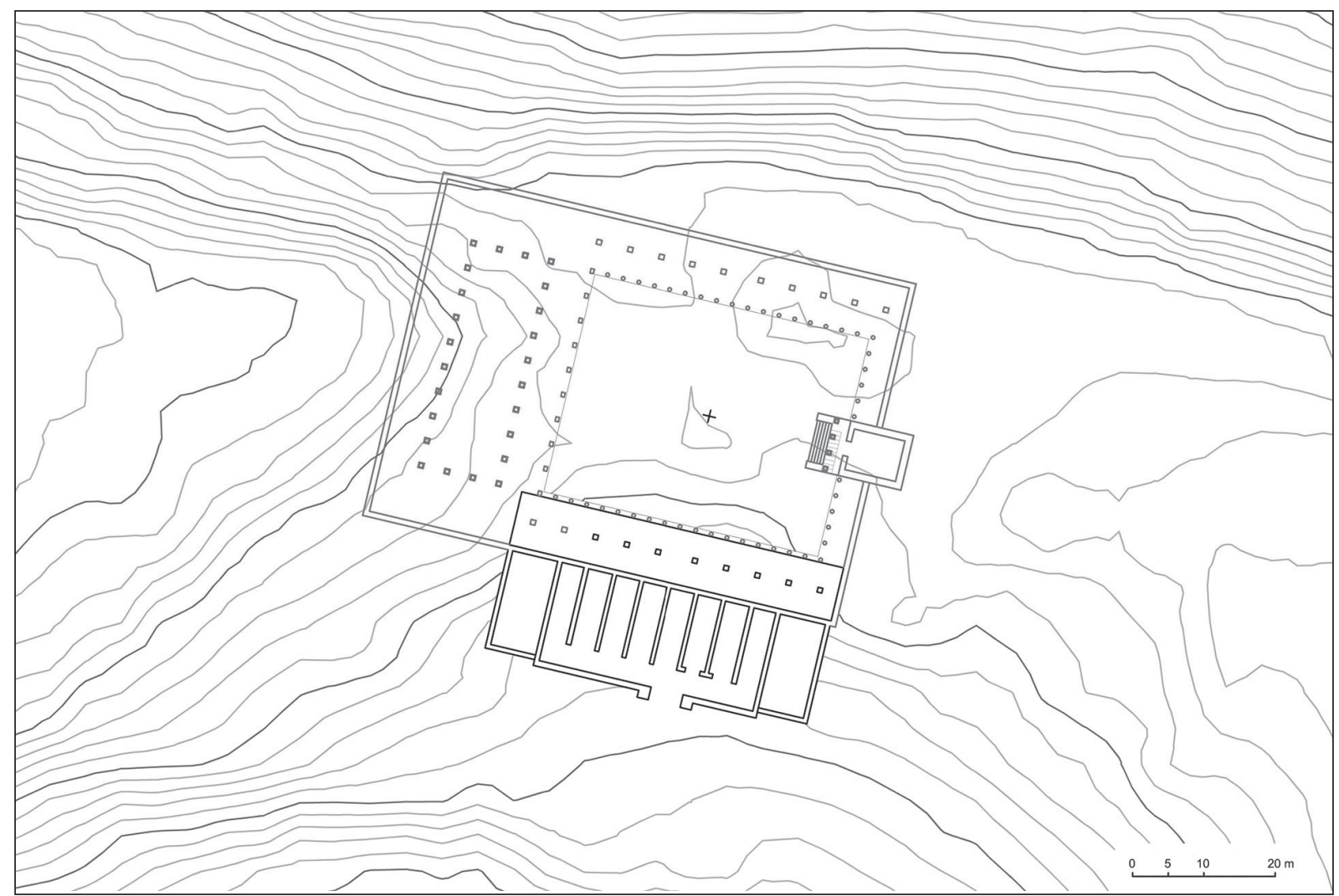

Figura 18. Propuesta interpretativa de la implantación del foro de Santa Criz en la orografía del cerro de Santa Criz (imagen: R. Cebrián).

Con una longitud máxima de 47,90 m -aproximadamente 161 pies-y una anchura de $8,19 \mathrm{~m}$, configuró una doble galería porticada al nivel de la plaza con columnas de orden dórico/toscano de aproximadamente 3,35 $\mathrm{m}$ de alto. La longitud del criptopórtico nos ofrece la extensión de uno de los lados de la plaza forense, que alcanzaría los 40,50 $\mathrm{m}$ al restar la anchura equivalente a los posibles pórticos este y oeste, que conjeturamos serían de una única nave. La presencia de una cornisa de esquina del orden dórico/toscano en el derrumbe del interior del criptopórtico asegura la presencia de un pórtico al menos por su lado occidental.

Frente a la ubicación teórica del templo se situaría la basilica forensis ocupando todo el costado occidental de la plaza, lo que explicaría que los elementos de su decoración aparecieran caídos y amontonados no solo en el extremo oeste del criptopórtico sino también en la posible caja de escalera de acceso a la plaza y en la nave más occidental del almacén. A su decoración arquitectónica se adscriben las basas, fustes y capiteles pertenecientes al orden corintio hallados en la excavación de los niveles de derrumbe. La mayor parte de las piezas constituye un conjunto homogéneo que corresponde a columnas de 5,90 m de altura. Al mismo sistema decorativo pertenecen las basas áticas, fustes y capiteles corintios de pilastra (primer grupo) y quizás también un fragmento moldurado, que permanece semienterrado en el nivel de derrumbe en el interior del criptopórtico, que podría corresponder a una cornisa con modillones.

El proyecto arquitectónico del foro debió seguir el módulo detectado en la construcción del criptopórtico y almacén. La porticus duplex que rodeó la plaza por el sur midió 27 pies de anchura, que equivaldría a 1 módulo de aproximadamente $8 \mathrm{~m}$. A partir de esta medida, y tomando en consideración la posible posición del templo, resulta una plaza de 5 x 4 módulos (en torno a $40 \times 48 \mathrm{~m}$ ), en cuyo eje central se situaría un templum, con fachada de 1 módulo, en el lado este y la basilica al oeste, de 6 x 3 módulos (aproximadamente 48 x $24 \mathrm{~m}$ ). Otra porticus duplex cerraría el conjunto por el lado septentrional. Su construcción tuvo que ceñirse al espacio disponible en la parte media del cerro, cuya longitud no supera los $75 \mathrm{~m}$ en dirección $\mathrm{N}-\mathrm{S}$, de manera que al situar el diseño propuesto sobre 
la planimetría y los restos excavados comprobamos que queda englobado en el terreno llano (fig. 18).

El esquema adoptado en el foro de Santa Criz respondería así a un modelo arquitectónico muy difundido por todas las regiones del Imperio a partir de época augustea, donde un templo se alzaría en uno de los lados cortos de la plaza y en el opuesto se situaría la basílica (Ward-Perkins 1970, Gros 1996: 207-234). Los restos de estatuas y pedestales (Andreu et al. 2019b: 24-27, n ${ }^{\circ} 1$ y $27-28, n^{\circ} 2$, probable) procedentes del estrato de derrumbe confirman que a lo largo de la vida del forum se fueron erigiendo estatuas para honrar a los nuevos magistrados o miembros de la familia imperial. El número de zócalos y coronamientos moldurados recuperados es de siete, dos de los cuales corresponden a estatuas ecuestres (Andreu et al. 2019b: 35-37, nº 5-6). Del mismo derrumbe proceden algunas inscripciones, una de ellas es el dado de un pedestal en el que se menciona al evergeta L. Aurelius Ursinus (Andreu et al. 2019b: 24-27, n 1), el cual por legado testamentario levantó acaso una estatua en honor a una divinidad. Una estatua togada, otra tipo Hüftmantel y algunas hojas de laurel de estatuas broncíneas atestiguan el programa estatuario erigido en honor de un emperador o miembros relevantes de la familia julioclaudia y las vincula al culto imperial (Andreu et al. 2019a: 47-49 y Romero 2018: 209). Por último, dos fragmentos de pulvini prueban la existencia de altares dedicados a diversas divinidades embelleciendo el conjunto forense (Andreu et al. 2019b: 37-40, $\mathrm{n}^{\circ}$ 6, 7 y 8).

Las hipótesis de ubicación de los edificios en torno a la plaza pública se solucionarán con las futuras excavaciones, que ayudarán a resolver los problemas históricos del origen, la temprana monumentalización, la promoción jurídica y el declive de este enclave del ámbito vascón. No obstante las excavaciones arqueológicas realizadas hasta la fecha permiten incluir a la civitas en la lista de enclaves hispanorromanos que construyeron su centro cívico en época augustea. A pesar de ello todavía en Santa Criz queda un forum por descubrir.

\section{Agradecimientos}

Apoyos recibidos para la realización del estudio: Proyecto de investigación financiado en el marco del Convenio de Colaboración entre la UNED de Pamplona, La Fundación Caja Navarra y la Obra Social La Caixa en el marco de las “Ayudas a la Investigación de 2018”. Convenio de colaboración suscrito entre el Ayuntamiento de Eslava y la Universidad de Navarra de cara a la dinamización cultural e investigadora del yacimiento.

\section{BIBLIOGRAFÍA}

Abascal, J. M.; Almagro-Gorbea, M. y Cebrián, R. (2007): "Parque Arqueológico de Segobriga. Últimos descubrimientos", en J. M. Millán y C. Rodríguez (coord.), Arqueología de Castilla-La Mancha: Actas de las I Jornadas: 385-398. Cuenca (2005), Cuenca, Universidad de Castilla-La Mancha.

Abascal, J. M.; Cebrián, R. y Trunk, M. (2004): “Epigrafía, arquitectura y decoración arquitectónica del foro de Segobriga", en S. F. Ramallo (ed.), La decoración arquitectónica en las ciudades romanas de Occidente: 219-256. Cartagena (2003), Murcia, Universidad de Murcia.

Adam, J.-P. (1989): La construction romaine. Matériaux et techniques. París, Picard.

Alarcão, J. de y Etienne, R. (1973): “L'architecture des cryptoportiques de Conimbriga (Portugal)", en Les cryptoportiques dans l'architecture romaine. Actes du Colloque de Roma: 371-405. Roma (1972), París, École Française de Rome.

Amy, R. (1973): “Les cryptoportiques d'Arles", en Les cryptoportiques dans l'architecture romaine. Actes du Colloque de Roma: 275-291. Roma (1972), París, École Française de Rome.

Andreau, J. (2007): "Conclusions du dossier. Pour l'étude des entrepôts antiques". Antiquités africaines 43: 261-264. <https://doi.org/10.3406/antaf.2007.1429>.

Andreu, J. (2006): "Ciudad y territorio en el solar de los vascones en época romana”, en J. Andreu (ed.), Navarra en la Antigüedad. Propuesta de actualización: 179-228. Pamplona, Gobierno de Navarra.

Andreu, J. (2010): "Un dispensator publicus en territorio vascón. A propósito de AE, 1971, 199 de Eslava (Navarra)", en Classica boliviana. Actas del IV Encuentro Boliviano de Estudios Clásicos: 177-190. La Paz (2010), Cochabamba, Sociedad Boliviana de Estudios Clásicos.

Andreu, J. (2011): "La ciudad romana de Los Bañales (Uncastillo, Zaragoza) en las fuentes históricas". Caesaraugusta 82: 19-100.

Andreu, J. (2017): "El territorio vascón y sus ciudades en la era de Augusto". Gerión 35: 551-569. <https:// doi.org/10.5209/GERI.56163>.

Andreu, J. (2018): "El hábito epigráfico entre los Vascones antiguos: Santa Criz de Eslava como paradigma". Príncipe de Viana 272: 1007-1027.

Andreu, J.; Armendáriz, J.; Ozcáriz, P.; García-Barberena, M. y Jordán, Á. A. (2008): "Una ciudad de los Vascones en el yacimiento de Campo Real/ 
Fillera (Sos del Rey Católico-Sangüesa)". Archivo Español de Arqueología 81: 71-100. <https://doi. org/10.3989/aespa.2008.v81.41>.

Andreu, J. y Armendáriz, J. (2018): “La vía romana de la Navarra Media entre las ciuitates de Campo Real/ Fillera de Sos del Rey Católico (Zaragoza) y Santa Criz de Eslava (Navarra): a propósito de un nuevo miliario procedente de Gabarderal", en R. Torres (ed.), Studium, magisterium et amicitia. Homenaje al profesor Agustín González Enciso: 41-48. Pamplona, Eunate Ediciones.

Andreu, J.; Delage, I.; Romero, L. y Mateo, Tx. (2019a): Santa Criz de Eslava, reflejos de Roma en territorio vascón. Pamplona, Servicio de Patrimonio Histórico del Gobierno de Navarra.

Andreu, J.; Ozcáriz, P. y Mateo, Tx. (2019b): Epigrafía romana de Santa Criz de Eslava (Eslava, Navarra). Faenza, Fratelli Lega Editori.

Aquilué, X.; Mar, R.; Nolla, J. M.; Ruiz de Arbulo, J. y Sanmartí, E. (1984): El Fòrum romà d'Empúries: (excavacions de l'any 1982): una aproximació arqueològica al procés històric de la romanització al nord-est de la Península Ibèrica. Barcelona, Diputació de Barcelona, Institut de Prehistòria i Arqueologia.

Aquilué, X.; Castanyer, P.; Santos, M. y Tremoleda, J. (2001): Empúries. Guides du Museu d'Arqueologia de Catalunya. Barcelona. Museu d'Arqueologia de Catalunya.

Armendáriz, J. (2008): De aldeas a ciudades. El poblamiento durante el primer milenio a. C. Navarra, Gobierno de Navarra.

Armendáriz, R. M ; Mateo, Mª R. y Sáez de Albéniz, $M^{a}$ P. (1996): "Primera campaña de excavación en el yacimiento de Santa Criz (Eslava, Navarra)". Trabajos de Arqueología de Navarra 12: 322-326.

Armendáriz, R. M ${ }^{\mathrm{a}}$; Sáez de Albéniz, $\mathrm{M}^{\mathrm{a}}$ P. y Mateo, $\mathrm{M}^{\mathrm{a}}$ R. (1997): "Prospección del término municipal de Eslava". Isturitz 7: 145-163.

Armendáriz, R. M M $^{\mathrm{a}}$ Mateo, M R. y Sáez de Albéniz, $M^{a}$ P. (2007): "La necrópolis de Santa Criz (Eslava)", en La tierra te sea leve. Arqueología de la muerte en Navarra: 149-155. Pamplona, Gobierno de Navarra.

Armendáriz, R. Mª Sáez de Albéniz, Mª P. y Diéguez, I. (2016): "Aproximación al paisaje urbano del yacimiento arqueológico de Santa Criz (Eslava)". Trabajos de Arqueología Navarra 28: 245-285.

Asensio, J. A. y Justes, J. (2014): "Nuevos datos acerca de la arquitectura y el urbanismo en el Municipium Osca. Arquitectura pública y privada en el sector sureste de la ciudad. El entorno del teatro". Bolskan 25: $15-50$.

Astolfi, F. (1996): "Horrea Agrippiana", en E.M. Steinby (dir.), Lexicon topographicum urbis Romae, III: 37-38. Roma, Quasar.

Beltrán Lloris, F. (2017): "Augusto y el valle medio del Ebro". Gerión 35: 525-540. <https://doi. org/10.5209/GERI.56160>.

Beltrán Lloris, M. (1982): La arqueología de Zaragoza. Últimas investigaciones. Zaragoza, Ministerio de Cultura-Excmo. Ayuntamiento de Zaragoza.

Beltrán Lloris, M. y Paz Peralta, J. A. (2014): Augustus: annus Augusti MMXIV. Zaragoza, Museo de Zaragoza.

Broise, P. (1969): “Éléments d'un ordre toscan provincial en Haute-Savoie". Gallia 27: 15-22. <https:// doi.org/10.3406/galia.1969.2516>.

Brown, F. E. (1979): Cosa. The Making of a Roman Town. Ann Arbor, University of Michigan Press.

Brown, F. E.; Richardson, E. H. y Richardson Jr. L. (1993): Cosa III: the buildings of the forum. Colony, municipium and village. Roma, American Academy in Rome.

Castiella, A. (2003): Por los caminos romanos de $\mathrm{Na}$ varra. Pamplona, Fundación Caja Navarra.

Chiner, P. (1990): La decoración arquitectónica en Saguntum. Valencia, Generalitat Valenciana.

Coarelli, F. (1982): Lazio. Guide archeologiche Laterza. Roma-Bari, Gius. Laterza\&Figli Spa.

De la Barrera, J. L. (1984): Los capiteles romanos de Mérida. Mérida, Museo Nacional de Arte Romano.

De la Barrera, J. L. (2000): La decoración arquitectónica de los foros de Augusta Emerita. Roma, L'Erma di Bretschneider.

Dell'Acqua, A. (2012): "Un capitello tuscanico da Ruselle”. LANX. Rivista della Scuola di Specializzazione in Archeologia - Università degli Studi di Milano 11: 21-34 <https://doi.org/10.13130/20354797/2411>.

Domingo, J. A. (2005): Capitells corintis a la provincia Tarraconense (s. I-III d.C.). Tarragona, Arola Editors y Ajuntament de Tarragona.

Domingo, J. A.; Garrido, A. y Mar, R. (2011): "Talleres y modelos decorativos en la arquitectura pública del noreste de la tarraconense en torno al cambio de era", en T. Nogales e I. Rodà (eds), Roma y las provincias: modelo y difusión. XI coloquio internacional de arte romano provincial: 851-862. Mérida (2009), Roma, L'Erma di Bretschneider.

Donzelli C. (1991): "Le strutture tardoantiche di Scolacium”. Mélanges de l'Ecole Française de 
Rome. Moyen Age 103-2: 485-503 <https://doi. org/10.3406/mefr.1991.3185>.

Erice, R. (2011): "El puerto fluvial de Caesaraugusta", en J. Arce y B. Goffaux (coord.), Horrea d'Hispanie et de la méditerranée romaine: 143-157. Madrid, Casa de Velázquez.

Escalada, F. (1943): La Arqueología en la villa y castillo de Javier y sus contornos. Pamplona, Leyre.

Escrivá, M. ${ }^{a}$ I. (2005): Basas romanas de la provincia Tarraconensis. Valencia, Institució Alfons El Magnànim.

Etxebarria, A. (2008): Los foros romanos republicanos en la Italia centro-meridional tirrena. Origen y evolución formal. Madrid, Consejo Superior de Investigaciones Científicas.

Excoffon, P. (2009): "Eléments de couverture en tuiles sciées de type corinthien à Olbia de Provence (Hyères, Var)". Documents d'Archéologie Méridionale 32: 255-267.

Fuentes, Á.; Escobar, R. y García, J. (2007): "Precisiones cronológicas sobre el origen del Foro de Valeria, Cuenca. (Resumen de los trabajos llevados a cabo durante las campañas del 2003-2005)", en $A r$ queología de Castilla-La Mancha, I Jornadas: 445468. Cuenca (2005), Cuenca, Universidad de Castilla-La Mancha - Junta de Comunidades de Castilla la Mancha.

Gimeno, J. (1989): “Tipología y aplicaciones de elementos dóricos y toscanos en Hispania. El modelo del Nordeste". Archivo Español de Arqueología 62: 101-139.

Gimeno, J. (1991): Estudios de arquitectura y urbanismo en las ciudades romanas del Nordeste de Hispania. Madrid, Universidad Complutense de Madrid.

Ginouvès, R. (1992): Dictionnaire méthodique de l'architecture grecque et romaine. II. Eléments constructifs: supports, couvertures, aménagements intérieurs. Rome, École Française de Rome.

Giuliani, C. F. (1973): "Contributi allo studio della tipologia dei cryptoportici”, en Les cryptoportiques dans l'architecture romaine. Actes du Colloque de Roma: 79-115. Roma (1972), París, École Française de Rome.

Guitart, J. y Padrós, P. (1990): "Baetulo. Cronología y significación de sus monumentos", en W. Trillmich y P. Zanker (eds), Stadtbild und Ideologie die Monumentalisierung hispanischer Städte zwischen Republik und Kaiserzeit: 165-178. Madrid (1987), München, Verlag der Bayerischen Akademie der Wissenschaften.

Goette, H. R. (1990): Studien zu römischen Togadarstellungen. Mainz, Verlag Ph. von Zabern.
Gros, P. (1981): Bolsena I. Scavi della scuola francese di Roma a Bolsena (Poggio Moscini). Guida agli scavi. Roma, École Française de Rome.

Gros, P. (1990): "Les étapes de l'aménagement monumental du forum: observations comparatives (Italie, Gaule, Narbonnaise, Tarraconaise)", en La Città nell'Italia settentrionale in étà romana. Morfologia, strutture e funcionamento dei centri urbani delle Regiones X e XI, Atti del convegno: 29-68. Trieste (1984), Rome, École Française de Rome.

Gros, P. (1996): L'architecture romaine. 1. Les monuments publics. París, Picard.

Gutiérrez Behemerid, M. A. (1992): Capiteles romanos de la Península Ibérica. Valladolid, Universidad de Valladolid.

Gutiérrez Behemerid, M. A. (2004): “Los programas arquitectónicos de época imperial en el conventus Cluniensis", en S.F. Ramallo (ed.), La decoración arquitectónica en las ciudades romanas de Occidente: 275-292. Cartagena (2003), Murcia, Universidad de Murcia.

Heilmeyer, W.-D. (1970): Korinthische Normalkapitelle: Studien zur Geschichte der römischen Architekturdekoration. Heidelberg, F. H. Kerle.

Hellmann, M.-C. (2002): L'architecture grecque. 1. Les principes de la construction. París, Picard.

Johannowsky, W. (1973): "Note sui cryptoportici pubblici in Campania", en Les cryptoportiques dans l'architecture romaine. Actes du Colloque de Roma: 143-165. Rome (1972), París, École française de Rome.

Larrañaga, K. (2007): El hecho colonial romano en el área circumpirenaica occidental. Vitoria, Universidad del País Vasco.

Luschin E. M. (2002): Cryptoporticus. Zur Entwicklungsgeschichte eines multifunktionalen Baukörpers. Viena, Österreichisches Archäologisches Institut.

Mar, R. (2005): El Palatí. La formación dels palaus imperials a Roma. Tarragona, Universitat Rovira $\mathrm{i}$ Virgili - Institut Català d'Arqueologia Clàssica.

Mar, R. y Pensabene, P. (2013): "El Foro de Segobriga y la formación de la arquitectura imperial en la Hispania romana: entre innovación y continuidades", en A. Sousa y M. do Carmo (coord.), História da Construçâo. Arquiteturas e Tecnicas construtivas, Centro de Investigaçâo Transdisciplinar Cultura, Espaço e Memória: 15-40. Braga, Centro de Investigação Transdisciplinar Cultura, Espaço e Memória - Laboratoire de Médiévistique Occidentale de Paris (Université de Paris 1 et CNRS). 
Mar, R.; Ruiz de Arbulo, J.; Vivó, D.; Beltrán-Caballero, J. A. y Gris, F (2015): Tarraco. Arquitectura y urbanismo de una capital provincial romana. vol. II. La ciudad imperial. Tarragona, Universitat Rovira i Virgili - Institut Català d'Arqueologia Clàssica.

Medrano, M.; Díaz Sanz, Ma A. y Tramullas, J. (1991): "Reconstrucción del edificio monumental de Contrebia Belaisca (Botorrita, Zaragoza)". Complutum 1: 281-292.

Moreno, I. (2008): Item a Caesarea Augusta Beneharnum. La carretera romana de Zaragoza al Bearn. Ejea de los Caballeros, Centro de Estudios Cinco Villas.

Noguera, J. M. y Madrid, Mª J. (2013): “Mármoles y marmorización arquitectónica en Nova Carthago: nuevas evidencias del Molinete", en V. García-Entero (ed.), El marmor en Hispania. Explotación, uso y difusión en época romana: 229-252. Madrid, UNED Editorial.

Olivier, A. (1982): "Dalles de toiture en pierre sciée à Glanum: opus pavonaceum?". Revue Archéologique de Narbonnaise 15: 69-101. <https://doi. org/10.3406/ran.1982.1199>.

Ortalli, J. (1995): “Complessi forensi e architetture civiche nelle città romane dell'Emilia Romagna: Ariminum, Sassina, Mevaniola, Veleia, Bononia", en M. Mirabella Roberti (coord.), Forum et basilica in Aquileia e nella cisalpina romana: 273-328. Udine, Arti Grafiche Friulane.

Papi, E. y Martorella, F. (2007): "I granai della Numidia". Antiquités africaines 43: 171-186. <https:// doi.org/10.3406/antaf.2007.1424>.

Pensabene, P. (1973): Scavi di Ostia VII. I Capitelli. Roma, Libreria dello Stato.

Poguet, M. y Pelletier, J.-P. (2004): “Eyguières. SaintPierre de Vence 1", en Bilan scientifique 2003 de la région Provence-Alpes-Côte d'Azur: 111-112. Aixen-Provence, Service Régional de l'ArchéologieDRAC.

Portillo, A. (2016): "La importancia del color en la arquitectura pública romana. Testimonios del empleo de marmora y pintura en algunos templos de la Bética". Cuadernos de Arqueología de la Universidad de Navarra 24: 21-48 <https://doi. org/10.15581/012.24.004>.

Ramírez Sádaba, J. L. (2009): "La toponimia de las ciudades vasconas", en J. Andreu (ed.), Los Vascones de las fuentes antiguas. En torno a una etnia de la Antigüedad peninsular: 127-146. Barcelona, Publicacions i edicions de la Universitat de Barcelona.
Ribera, A. (2011): "Los horrea de Valentia. De la Republica al Imperio", en J.Arcey y B. Goffaux (coord.), Horrea d'Hispanie et de la méditerranée romaine: 201-223. Madrid, Casa de Velázquez.

Rickman, G. (1971): Roman granaries and store buildings. Cambridge, Cambridge University Press.

Roth-Congès, A. (1992): "Le centre monumental de Glanon, ou les derniers feux de la civilisation salyenne". Marseille Grecque et la Gaule 3: 351-367.

Rodríguez Gutiérrez, O. (2004): El teatro romano de Itálica: estudio arqueoarquitectónico. Madrid, Universidad Autónoma de Madrid.

Rodríguez Neila, J. F. (1997): “Apparitores y personal servil en la administración local de la Bética”. Studia Historica. Historia Antigua 1: 197-228.

Romero, L. (2014): "Novedades en los fora del conuentus Caesaraugustanus". Bolskan 25: 195-218.

Romero, L. (2017): "La basílica del foro de Los Bañales (Uncastillo, Zaragoza). Habis 48: 113-131.

Romero, L. (2018): “Fora vasconiae. Centros cívicos en los límites del conventus Caesaraugustanus: el caso de Santa Criz de Eslava (Eslava, Navarra)". Trabajos de Arqueología Navarra 30: 197-214.

Romero, L. (en prensa): "The roman forum of Los Bañales (Uncastillo, Zaragoza): Building, remodelling and reutilisation of a forum from the conuentus Caesaraugustanus", en 19th International Congress of Classical Archaeology: s. pp. Colonia-Bonn (2018), Colonia/Bonn, Oxford, Oxbow Books, e.p.

Roth-Congès, A. (1983): "L'acanthe dans le décor architectonique protoaugustéen en Provence". Revue Archéologique de Narbonnaise 16: 103-134. $<$ https://doi.org/10.3406/ran.1983.1226>.

Rossignani, M. P. (1995): "Foro e basilica a Luni", en M. Mirabella Roberti (coord.), Forum et basilica in Aquileia e nella cisalpina romana: 443-466. Udine, Arti Grafiche Friulane.

Ruyt, C. de (1983): Macellum. Marché alimentaire des Romains. Lovaina-la-Nueva, Dubois-Pèlerin.

Sebastiani, R. y Serlorenzi, M. (2011): "Nuove scoperte dall'area di Testaccio (Roma): tecniche costruttive, riuso e smaltimento dei contenitori anforici pertinenti ad horrea e strutture utilitarie di età imperiale", en J. Arce y B. Goffaux (coord.), Horrea d'Hispanie et de la méditerranée romaine: 67-95. Madrid, Casa de Velázquez.

Sisani, S. (2006): Umbria. Marche. Guide Archeologiche Laterza 7. Roma, Laterza.

Taracena, B. y Vázquez de Parga, L. (1946): "Excavaciones en Navarra. V. La Romanización”. Príncipe de Viana 24: 413-470. 
Trunk, M. (2008): Los capiteles del foro de Segóbriga. Evaluación tipológica y estilística. Cuenca, Consorcio del Parque Arqueológico de Segóbriga.

Ward-Perkins, J.B. (1970): "From Republic to Empire: Reflections on the Early provincial Architecture of the Roman West". The Journal of Roman Studies 60: $1-19$

Vargas, S. (2018): "La techumbre marmórea del Traianeum de Italica", en J. Beltrán, M. L. Loza y E. Ontiveros (coord.), Marmora Baeticae: Usos de materiales pétreos en la Bética romana. Estudios arqueológicos y análisis arqueométricos: 215-222. Sevilla, Editorial Universidad de Sevilla.

Velaza, J. (1995): "Epigrafía y dominios lingüísticos en territorio de Vascones", en F. Beltrán Lloris (ed), Roma y el nacimiento de la cultura epigráfica en Occidente: 209-218. Zaragoza, Institución Fernando el Católico.

Zuza, C. (2013): "El patio oriental de la villa romana de Liédena (Navarra) en el Bajo Imperio y la annona militaris: una propuesta". Cuadernos de Arqueología de la Universidad de Navarra 21: 291-308. 